Boros Anita - Hegedüs Viktor - Iván Dániel

\title{
A FENNTARTHATÓSÁG TÁRSADALOMPOLITIKAI INDIKÁTORAI ÉS AZOK HAZAI TELJESÜLÉSE ${ }^{1}$
}

\author{
Indicators of Social Policy for Sustainability and Their Fulfilment in Hungary
}

Dr. habil. Boros Anita LL.M. egyetemi docens, Nemzeti Közszolgálati Egyetem, Államtudományi és Nemzetközi Tanulmányok Kar, Lörincz Lajos Közigazgatási Jogi Tanszék, kutatóprofesszor, Széchenyi István Egyetem, Globalizációs Kompetencia Központ, elnök, Közigazgatási Eljárási Jogi Egyesület, boros.anita@uni-nke.hu

Hegedüs Viktor, nemzetközi tanulmányok mesterszakos hallgató, Nemzeti Közszolgálati Egyetem, Államtudományi és Nemzetközi Tanulmányok Kar, hegedus.viktor0@gmail.com

Dr. Iván Dániel, egyetemi tanársegéd, Nemzeti Közszolgálati Egyetem, Államtudományi és Nemzetközi Tanulmányok Kar, Lőrincz Lajos Közigazgatási Jogi Tanszék, titkár, Közigazgatási Eljárási Jogi Egyesület, ivan.daniel.@uni-nke.hu

A fenntarthatóság, a fenntartható fejlödés a jelenkor egyik kiemelkedően aktuális és sokat kutatott területe. Tanulmányunk a fenntarthatóság fogalmi kereteinek vizsgálata során történeti megközelitést alkalmazva próbál rávilágitani a fenntarthatóság és a fenntartható fejlödés értelmezésének alakulására, valamint a két fogalom közti kapcsolatra. A fenntarthatóság fogalmi meghatározása mellett a mérésére kialakított indikátorokat, illetve indikátorkészleteket mutatjuk be, valamint azok gyakorlati alkalmazása során felmerülö kérdések kerülnek górcső alá. A tanulmány keretein belül megvizsgáljuk a fenntarthatóság társadalompolitikai területének mérésére kialakitott mutatókészleteket, és bemutatjuk hazai alakulásukat és teljesülésüket.

KulcsszavaK:

fenntarthatóság, fenntartható fejlődés, társadalmi fenntarthatóság, indikátorok, fenntarthatósági indikátorok, fenntarthatóság mérése

A tanulmány a Nemzeti Közszolgálati Egyetem „Fenntartható biztonság és társadalmi környezet” című projektjében, a 2019. évi Tématerületi Kiválósági Program keretében jött létre. 
The phenomenon of sustainability and sustainable development is one of the most current and most researched domains. In our present study a close, historic approach is applied to the conceptual framework of these two concepts and their relation. Besides presenting the evolving definition of sustainability, our work aims to examine the available indicators and set of indicators to measure general sustainability from the viewpoint of social policy; furthermore, the questions arising from their application in practice are analysed. We concluded in our paper that the concept of sustainability is well-researched and developed, in contrast, the indicators measuring it need further elaboration. Finally, the last section studies the realisation and evolution of the available social policy indicators of sustainability in Hungary.

\section{KeYWORDS:}

sustainability, sustainable development, social sustainability, indicators, sustainability indicators, measuring sustainability 


\section{BEVEZETÉS}

Az emberiség története óta nem, vagy nem ilyen léptékben és súlyossággal jelentkező, globális méreteket öltő éghajlati, környezeti fenyegetések megjelenése, a globális fogyasztás és a népességszám folytonos növekedése és kielégítése a gazdasági növekedésünk és a felhasználási szokásaink új alapokra helyezését követeli meg. A globális túlfogyasztás napja egyre korábbra datálódik, ${ }^{2}$ Magyarországon 2018 után 2019 ismét rekordot döntött a legmelegebb év tekintetében, és az első tíz legmelegebb év közül nyolc az ezredfordulót követő évek során volt tapasztalható. ${ }^{3}$ A bolygónk népességszámának folyamatos emelkedésével a világ eröforrásigénye is párhuzamosan nő, amely az életszínvonal emelésére való törekvéssel szintén egyre tovább növekvő tendenciát fog mutatni. A probléma megoldása azonban nem lehet a lakosságnövekedés vagy az életszínvonal-emelkedés tendenciájának megállítása. A megoldás sokkal inkább a jelenlegi rendszereink átalakításában rejlik; a felhasználási módjainkban tükröződnie kell a környezetünk, a társadalmunk és a gazdaságunk természetes határainak. A természeti erőforrások végessége által szabott határok körvonalazódása kijelöli létünk és határtalanként kezelt fejlődésünk korlátait, amelyek figyelmen kívül hagyását nem tehetjük meg az elkövetkezendő nemzedék lehetőségeinek beszűkülése és az ökológiai katasztrófa elkerülése végett.

A tudományok területén belül az ökológiai rendszer által szabott korlátok és a növekedésünk végességének figyelembevételét szem előtt tartó növekedési modellként egyre több figyelem övezi a fenntarthatósági elveket, valamint a fenntartható fejlődésként fémjelzett növekedési formát. A megjelenő ökológiai kihívások összetett jellegéből és a globális lefedettségből és érintettségből fakadóan nehezen lehetne ezekre egyszerü megoldást adni, azonban az életmódunk jelenlegi szintjének megtartása (valamint annak továbbemelése) érdekében új fogyasztási, termelési és döntési szokásokat szükséges elfogadni és normává alakítani, egyéni és társadalmi szinten egyaránt. Az ökológiai katasztrófa elkerülése érdekében a szakirodalom és a nemzetközi közösség által kidolgozott és kiaknázható lehetőségként a fenntartható fejlődés irányába történő elmozdulás jelentheti a megoldást. A fenntartható fejlődés által jelzett növekedési modellnek a lényege nem csupán a hagyományos közgazdasági föáramlathoz tartozó növekedési mutatók (például GDP) ${ }^{4}$ hosszú távú, töretlen növelésére összpontosul, hanem a több, egymással összefüggő társadalmi, természeti és gazdasági tényező együttes figyelembevételével történő növekedésnek a fenntartható fejlesztésére irányuló törekvéseként összegezhető.

2 A globális túlfogyasztás azt az időpontot jelöli, amikor a Föld lakosai felhasználták azt a mennyiségű erőforrást, amelynek egy teljes évre kellene elegendőnek lennie ahhoz, hogy a bolygónk jelenlegi állapotában fennmaradhasson. Az elmúlt években egyre korábbra tehető, tehát a Föld túlfogyasztása folyamatosan nő. 2019-ben július 29-re esett, az azt megelőző évben pedig augusztus 1-jére.

32019 a legmelegebb év 1901 óta Magyarországon. OMSZ, 2020. Elérhető: www.met.hu/omsz/OMSZ_hirek/index. php?id=2729\&hir=2019_a_legmelegebb_ev_1901_ota_Magyarorszagon (A letöltés dátuma: 2020. 06. 01.)

4 A fenntarthatóság fogalmának változása mellett a fejlődés szintén terjedelmes tudományos vita tárgyát képezi, lásd növekedéselmélet és egyéb diskurzusok. 
A fenntarthatósági elvek gyakorlatba ültetése érdekében szükséges a folyamatnak a közelről történő mérése és elemzése. A fenntarthatóság fogalmi témaköre mellett a folyamat mérésére alkalmas mutatók esetén ugyancsak széles körü szakirodalom áll rendelkezésre, ugyanakkor e tudományos folyamat közel sem tekinthető konszenzuálisan elfogadottnak, illetve befejezettnek. ${ }^{5} \mathrm{~A}$ jelenleg elérhető mutatók, illetve mutatókészletek vizsgálata során érdemes kiemelni, hogy több esetben egyetlen indikátorban kívánják megragadni számos, sokszor rendkívül összetett folyamat és terület adatait, illetve az adatok változásait, ezáltal elérhetővé téve a szélesebb körü közönség számára a hozzáférhetőséget. ${ }^{6}$ Ezek (a hagyományos fenntarthatóság fogalmának dimenziói esetén) a környezet, a gazdaság és a társadalom erőforrásait és azok alakulását kívánják bemutatni. Ilyen jellegü tudományos vállalkozásnál kulcsfontosságú a fogalmi keretek megalkotása, mivel ez befolyásolja a kapott értéket, hiszen hatással van arra, hogy maga a mérési rendszer mit és milyen jelenségeket képes kvantitatív módon mérni. Ebből kiindulva fontosnak tartjuk, hogy egy rövid kitekintés erejéig bemutassuk a fenntarthatóság fogalmi kereteit, valamint e témán belül külön kiemelten foglalkozzunk a fenntarthatóság társadalmi mutatóival és azok teljesülésével.

A politikai együttműködések terén egyre több kezdeményezés született az elmúlt évtized során, amelyek nemzetközi szinten kívánják előmozdítani a létünket fenyegető ökológiai kockázatok enyhítését célzó politikákat. ${ }^{7}$ A Párizsi Megállapodás példának okáért a globális felmelegedést kívánja lassítani, illetve csökkenteni a csatlakozott országok üvegházhatású gázok (ÜHG-gázok) légkörbe juttatását. Az Egyesült Nemzetek Szervezete (ENSZ) által 2015-ben kidolgozott Fenntartható Fejlődési Célok (Sustainable Development Goals - SDG-célok), amelynek előzménye az ezredfordulón kialakított Milleniumi Fejlesztési Célokban (Millennium Development Goals - MDG) gyökerezik, mára talán az egyik legtöbbet hivatkozott nemzetközi együttmüködési keretrendszert adja. A nemzetközi együttmüködések egyre részletesebb kidolgozottsága és számszerű növekedésük jelzi, hogy felértékelődött a fenntartható fejlődés iránti elkötelezettség és áttérési szándék, ugyanakkor ezek az együttmüködések csupán annyira lehetnek sikeresek, amennyit az egyes államok megvalósítanak belőlük. Ebből kifolyólag a nemzetállamok a fenntarthatósági elvek gyakorlatba történő átültetését hosszú távú stratégiák és célkitűzések kidolgozása mellett, a tényleges szakpolitikai cselekvések formájában valósíthatják meg. Jelen

A fenntarthatóság fogalmi megragadása és annak lényegi tartalma kihat a folyamat mérésére kialakított indikátorokra, illetve indikátorkészletekre. A fogalmi keretek egységességének hiánya és folyamatos alakulása a fenntarthatósági indikátorok kialakításának komplikáltságát eredményezi. Bővebben ld.: Karcagi-Kováts Andrea: Mivel mérjük a fenntarthatóságot? - Az indikátorkészletek helyzetértékelése az EU tagállamok nemzeti fenntartható fejlődési stratégiáiban. Doktori értekezés. Debrecen, Debreceni Egyetem, 2011. 21-24.

6 Kárpáti Zoltán - Vári Anna - Ferencz Zoltán: Társadalmi fenntarthatósági indikátorok életciklus megközelítésben - egy kutatás tapasztalatai. Kultúra és Közösség, 2. (2011), 3. 15-28. 15.

A fenntarthatósági szakpolitikák elterjedésének alakulásáról és részletességeiről bővebben 1.: Sustainable transitions: policy and practice. EEA Report No. 9/2019. Luxembourg, European Environment Agency, 2019. Elérhető: www.eea.europa.eu/publications/sustainability-transitions-policy-and-practice (A letöltés dátuma: 2020. 05. 31.) 
tanulmánnyal e folyamatot kívánjuk segíteni, és hiszünk abban a tudományos tételben, hogy a fenntarthatósági indikátorok változásainak vizsgálata hozzájárul a fenntarthatóság elveinek gyakorlati megvalósításához.

A fenntarthatóság eszméje a pazarló fogyasztói társadalom jelenségére, a globális éghajlatváltozás egyre szélsőségesebbé válására és a mára már rendszeresen előforduló környezeti katasztrófákra, válságokra, illetve az ezek által generált összetett politikai és gazdasági krízisekre adható lehetséges megoldás. A növekvő hulladékmennyiség és fogyasztási szokásaink összessége a bolygónk által biztosított erőforrások feléléséhez vezet, amelynek megelőzésére kell törekednünk, hiszen mindannyiunk és az elkövetkezendő generációk életét egyaránt ellehetetlenítheti. A gazdasági növekedés és jólét eddigi ismereteit új összefüggésekben szükséges vizsgálni és megvalósítani, amelyek figyelembe veszik a környezetünk állapotát és az ökológiai diverzitás megőrzését.

Jelen tanulmány szerkezeti és logikai felépítése az alábbi: az első fejezetben röviden bemutatjuk a fenntarthatóság eszméjének történeti előzményét, valamint kapcsolatát a fejlődés fogalmával. Ezt követően kitérünk e jelenség mérésére elérhető és alkalmas mutatók, illetve mutatókészletek bemutatására. Legvégül pedig megvizsgáljuk ugyanezen mutatók társadalompolitikai szempontból történő alakulását, valamint azok hazai teljesülését és változásait.

\subsection{A fenntarthatóság és a fejlödés kapcsolata, eredete és rövid története}

A fenntarthatóság, a fenntartható fejlödés, a fenntartható növekedés számos esetben egymás szinonimájaként kezelt fogalmak. A fenntarthatóság általánosan elfogadott fogalmi keretei több tudományos fordulaton és tartalmi fejlődésen estek át. Ebből kifolyólag szükségesnek tartjuk, hogy a fenntarthatóság és a fenntartható fejlődés fogalmi világát és fejlődését röviden összefoglaljuk, hiszen a fogalmi keretek változása erős összefüggést mutat a fenntarthatóság mérésére kialakított mutatókkal. ${ }^{8}$ Rövid áttekintésünkben szeretnénk megragadni a fenntarthatóság elveinek megszületéséhez és elterjedéséhez vezető utat, valamint bemutatjuk a fenntarthatóság és a fejlödés kapcsolatát.

Susan Murcott 1997-ben 57 különböző fenntarthatósági definíciót gyűjtött össze kutatásában, ${ }^{9}$ amely rámutat az egységes megközelítés hiányára és sokoldalúságára. Ez azóta sem változott, sőt, a fenntarthatóság fogalmi szempontból jelentősen bővült, továbbá ugyanezen jelenség kvantitatív leírására alkalmas mutatónak (illetve mutatóinak) megalkotása sem egy lezárult tudományos folyamat. Tudományos szempontból célunk nem az egyedüli fenntarthatóság fogalmi megragadása, sokkal inkább arra kívánunk rávilágítani, hogy mennyire szerteágazó gondolati elemekből áll össze maga a fenntarthatóság fogalma.

Karcagi-Kováts i. m. (5. lj.) 25.

Fleischer Tamás: A fenntarthatóság mérése. In Knoll Imre - Lakatos Péter (szerk.): Közszolgálat és fenntarthatóság. Budapest, Nemzeti Közszolgálati Egyetem, 2014b. 25-47. 25. 
Ugyanebből kifolyólag a mérése is rendkívül összetett feladat, amelyre a későbbiekben térünk ki részletesebben.

A fenntarthatóság jelenségének megszületéséig több mérföldkőként kezelhető alkotást említhetünk. Rachel Carson Néma tavasz címü kötete 1962-ben jelent meg, amelynek központi témája a mezőgazdaságban használt vegyi anyagok állatra és emberre egyaránt veszélyes hatásai, így felhívva a figyelmet a környezet pusztulásának folyamatára. ${ }^{10}$

Paul Ehrlick 1968-ban a Népességrobbanás című munkájában az emberi populáció ugrásszerű emelkedésével összefüggésben annak erőforrásigényekre gyakorolt hatásait fejtette ki, és utalt az ezáltal előidézett környezeti problémákra. ${ }^{11}$

Ezt követően 1969-ben érkezett a legújabb környezetvédelmi kezdeményezés, amely a Föld Barátai (Friends of Earth) nevet kapta, és a környezet pusztulási folyamatának megállítását, a biológiai sokféleség megőrzését, valamint azon gazdasági hajtóerők megállítását tűzte ki célul, amelyek a környezeti romboláshoz vezetnek. Hasonlóan 1969-ben, az ENSZ akkori fötitkára, U Thant emelte fel hangját a nemzetközi közösséget figyelmeztetve, hogy az emberiség a környezeti katasztrófa jelenségével néz szembe, amennyiben nem változnak jelentősen az addigi környezeti folyamatok. ${ }^{12}$ Mindezen elözmények erőteljesen hozzájárultak és megalapozták az ENSZ által megrendezett környezeti konferencia későbbi alakulását, amelynek eredményeképpen megszületett a Közös jövőnk című jelentés.

A fenntarthatóság gyakorlati kérdései már az ókori Egyiptom, Mezopotámia életében is megjelentek, valamint olyan korabeli tudósok figyelmét keltette fel, mint Platón, Sztrabón vagy Columella. ${ }^{13}$ Már ekkor nemcsak felismerték az ember akkori gazdasági tevékenységeinek káros következményeit és azok jövőbeni kockázatait, hanem megállapították, hogy kellő gyakorlatok követése szükséges a Föld „fiatalságának örök megörzéséhez”. Maga a fenntarthatóság terminusa először Hans Carl von Carlovitz Sylvicultura Oeconomica munkájában jelent meg, az erdők erőforrásainak fenntartható felhasználásának tekintetében. ${ }^{14}$ Az Egyesült Királyságban William Stanley Jevons, míg Németországban Rudolf Clausius már 1866-ban figyelmeztet arra, hogy erőforrásaink végesek, és kimerüléssel fenyegetnek. ${ }^{15}$ A történeti részt idézve érdekességként kiemeljük Alfred Russel Wallace

Részletesebben 1.: Rachel Carson: Silent Spring. Houghton Mifflin, 1962.

Részletesebben 1.: Paul R. Ehrlick: The Population Bomb. New York, Sierra Club/Ballantine Books, 1968.

2 Mészáros Dóra: A mezőgazdaság fenntarthatóságát értékelő módszer fejlesztése. Doktori értekezés. Gödöllő, Szent István Egyetem, 2017. 7.

13 Jacobus A. Du Pisani: Sustainable Development - Historical Roots of the Concept. Environmental Sciences, 3. (2006), 2. 83-96. 85.

14 Markó Lilla: Mit jelent valójában a fenntartható fejlődés? - A fenntarthatóság és a fenntartható fejlődés fogalmi keretei. In Nyirkos Tamás (szerk.): Közös jövőnk - A fenntarthatóság elmélete és gyakorlata. Ostrakon Hallgatói Szervezetért Közhasznú Egyesület, 2017. 9-10. 9. Elérhető: https://btk.ppke.hu/uploads/articles/956050/ file/1704921\%20-\%20P\%C3\%A1zm\%C3\%A1ny\%20Ostrakon\%20-\%20online_v2.pdf (A letöltés dátuma: 2020. 06. 01.); részletesebben 1.: Thomas R. Malthus: Essay on the Principle of Population. London, Electronic Scholarly Publishing Project, 1998 [1798].

15 Du Pisani i. m. (13. lj.) 86.; részletesebben 1.: Jevons, William S.: The Coal Question: An Inquiry concerning the Progress of the Nation, and the Probable Exhaustion of our Coal-mines. London, Macmillan, 1865. 
1898-as művét, mivel jórészt az általa megfogalmazott kérdéskörök alkotják a későbbi, 20. század derekától kezdődő fenntarthatóság tudományos diskurzusainak fó áramlatait. ${ }^{16}$

E sarokpontok eszmetörténeti szempontból kiemelendők, hiszen egyre inkább előtérbe került azon felfogás, hogy a határtalanként kezelt és töretlen növekedésünk igen is véges természeti korlátokkal rendelkezik. A fenntarthatóság fogalmi kereteinek kialakulása elméletben éppen ezt kívánja megragadni, tudniillik, hogy a gazdasági teljesítménynek külső feltételei is vannak. A környezeti kérdések tekintetében azonban a szélesebb közönség számára az 1970-es évek hozta el a fordulópontot, ugyanis az ENSZ emberi környezeti konferenciája, valamint a Római Klub támogatásával megjelent tanulmánynak köszönhetően ismerhettük meg a fenntartható fejlődés fogalmát először. ${ }^{17}$ Ezt felhasználva, valamint e tudományos alapra támaszkodva fejlődött tovább a későbbiekben a fenntarthatóság.

A ma széles körben ismert fenntartható fejlődés fogalmi gyökerei az 1987-ben felállított ENSZ Környezet és Fejlődés Világbizottságának, ismertebb és rövidebb nevén a Brundtland-bizottság által készített Közös jövőnk címmel ellátott jelentéséből eredeztethető. A nemzetközi átvétel, illetve a fenntartható fejlődés talán legtöbbet idézett fogalma ide vezethető vissza. A Brundtland-jelentés alapján a fenntartható fejlődés a következőt takarja: „A fejlödés olyan formája, amely a jelen igényeinek kielégítése mellett nem fosztja meg a jövő generációit saját szükségleteik kielégitésének lehetőségétől." ${ }^{\text {"18 }} \mathrm{Az}$ ez előtt megjelenő fogalmakhoz képest e jelentés az intragenerációs fogalommal egészítette ki a fenntarthatóság elméletét. E forrás alapján emellett tehát egy olyan alternatívát kíván nyújtani a növekedési modellek között, amely figyelembe veszi a növekedés elengedhetetlen forrásait. A Brundtland-jelentésben foglaltak népszerűsége és széles körü átvétele elsősorban annak tág és laza fogalmazásában található, amivel egyúttal számos kritikát is vont maga után. A szakirodalmi áttekintés során meglehetősen vegyes véleményeket találunk a jelentésben foglaltak értékelését tekintve. Az általános, széles körü átvételét épp a laza megfogalmazásának és tág, politikailag is széles körben értelmezhetőségének köszönheti. A Brundtland-bizottság magyar akadémikusa, Láng István is kiemeli, hogy ez a megfogalmazás elsősorban politikai tartalmú. ${ }^{19}$

A Brundtland-jelentés a fenntarthatóságnak a hagyományos megközelítését három dimenzió alapján értelmezi: a gazdaság, a társadalom és a környezet. A fenntarthatóság elméleti megközelítésében e három tényező egyenlő módon történő érvényesülése és védelme szükséges az elv alapvető célkitüzésének megvalósulása érdekében. A fentarthatóság tehát nem csupán gazdasági növekedést kíván elérni, hanem oly módon teszi ezt, hogy a humán és környezeti források végességének figyelembevételével és azok felélésmentes felhasználásával történjen mindez.

\footnotetext{
Markó i. m. (14. lj.) 9.

17 Részletesebben 1.: Meadows et al. 1972; Danny Stofleth: A short history of sustainable development. Rethinking Proseperity Blog, 2017. 02. 23. Elérhető: http://rethinkingprosperity.org/a-short-history-of-sustainabledevelopment/ (A letöltés dátuma: 2020. 06. 02.)

18 Persányi Miklós (szerk.): Közös jövőnk. Budapest, Mezőgazdasági Kiadó, 1988. 68.

19 Karcagi-Kováts i. m. (5. lj.) 31.
} 
A Brundtland-jelentést követően 1992-ben került megrendezésre Rio de Janeiróban a Környezet és Fejlődés Konferenciája, majd 1997-ben Kyotoban erősítették meg a fenntartható fejlődés elveit. A ma talán legszélesebb körben ismert ENSZ SDG fejlődési célok előzményeként az ezredfordulón határoztak a Milleniumi Fejlődési Célok (MDG-célok) megalkotásáról, amely 2000 és 2015 között vizsgálta a fenntarthatóság számos területét és jelentős lépésként értelmezhető a fenntartható fejlődés elemzése szempontjából. ${ }^{20}$ Az MDG-célok korszerűségének végével újabb módszert dolgoztak ki, amelynek keretében az előbbiekhez képest 17 fö célt és 169 részcélt fogalmaztak meg, megközelítőleg 230 indikátorral. Jelenleg ez a nemzetközi kezdeményezés adja a fenntartható fejlődésre való törekvésnek a legszélesebb lefedését.

A szakirodalmi szerzők vizsgálatakor azonban megjelenik a fenntartható fejlődés (sustainable development) mellett a fenntarthatóság (sustainability), illetve néhol a fenntartható fejlesztés fogalma (angol fordításban szintén „sustainable development”), miközben több szerző sem használja következetesen e fogalmakat, mivel nem a lényegi tartalmát alkalmazzák. A nemzetközileg elterjedt „sustainable development” sokkal inkább fenntartható fejlesztésként fordítható, a szakirodalom azonban ezt nagyon kevés alkalommal használja következetesen. ${ }^{21}$ A terminológiai meghatározás így tehát az egész fenntarthatóságról alkotott diskurzusnak fontos eleme, azonban ennek meghatározása sem egyszerü önmagában. A fenntarthatósági indikátorok esetén a későbbiekben láthatjuk, hogy számtalan típusú indikátort dolgoztak ki, amelyek a fenntarthatóságnak bizonyos oldalára koncentrálnak.

\subsection{A hazai fenntarthatósági törekvések és annak keretei, valamint a fenntarthatóság dimenziói}

A Fenntartható Fejlődési Keretrendszer 2030 elfogadása után Magyarországon létrejött egy koordinációs mechanizmus a szaktárcák között a hazai végrehajtás koordinációjáért felelős Külgazdasági és Külügyminisztérium (KKM) vezetésével. Az Agenda 2030 hazai végrehajtásának első fázisában a koordináció a már müködő NEFE Tárcaközi Koordinációs Bizottságon keresztül valósult meg. 2017-ben a KKM egy új tanácsadó platformot hozott létre az Agenda 2030 végrehajtásában érdekelt felek bevonásával, amely nagymértékben előmozdította mind a szakpolitikák fenntartható fejlődési célú koherenciájának megvalósulását, mind pedig az Agenda 2030 hazai végrehajtását. ${ }^{22}$ A platform

20 Stachó Krisztina: Világunk átalakítása: a fenntartható fejlődés 2030-ig szóló ENSZ-programja. In Nyirkos Tamás (szerk.): Közös jövőnk - A fenntarthatóság elmélete és gyakorlata. Ostrakon Hallgatói Szervezetért Közhasznú Egyesület, 2017. 9-10. 12. Elérhető: https://btk.ppke.hu/uploads/articles/956050/file/1704921\%20 -\%20P\%C3\%A1zm\%C3\%A1ny\%20Ostrakon\%20-\%20online_v2.pdf (A letöltés dátuma: 2020. 06. 02.)

21 A fenntartható fejlesztés arra utal, hogy tudatos, célszerü emberi tevékenység eredményeként szándékolt következménye a fenntarthatóság alatt értett rendszer felé való közeledés.

22 A hazai fenntarthatósági indikátorok összevetése során kivehető, hogy a magyar indikátorok keretrendszere a régión belüli és európai uniós összevetést tekintve is önálló, külön rendszert alkot, valamint a leg- 
a kormányzati szereplőkön kívül magában foglalta a Központi Statisztikai Hivatalt (KSH), valamint a civil szervezetek, a tudományos és a privát szektor képviselőit. Az utókövetés és felülvizsgálat tekintetében a KSH proaktívan részt vesz a Fenntartható Fejlődési Célok nemzeti és globális szintű megvalósításának elősegítésében.

Az EU szintén elkötelezte magát az Agenda 2030 megvalósításában. 2017 júniusában az Általános Ügyek Tanácsán az Agenda 2030 végrehajtására vonatkozó európai uniós tanácsi következtetéseket elfogadták, amelynek eredményeként felállították az Agenda 2030 végrehajtásával foglalkozó új tanácsi munkacsoportot, az Agenda 2030 munkacsoportot, valamint egy, az érdekelt feleket tömörítő platformot, a Multistakeholder Platformot. Ez utóbbi ajánlásokat fogalmaz meg az uniós szintű végrehajtás terén.

A fenntartható fejlődés magyarországi keretrendszerének alapjául a Nemzeti Fenntartható Fejlődési Tanács (NFFT) által kidolgozott és 2013-ban az Országgyülés által is elfogadott NFFK szolgál. ${ }^{23} \mathrm{E}$ dokumentum a fenntarthatóság hárompilléres megközelítését kibővítve, négy külön területre osztva közelíti meg a fenntartható fejlődést, amelyek feltétlenül szükségesek „minden nemzedék anyagi, szellemi és lelki jólétének elősegítéséhez": ${ }^{24}$ az emberi (humán), a társadalmi, a természeti és a gazdasági erőforrást jelöli meg. ${ }^{25} \mathrm{Az}$ NFFK esetén érdemes kiemelni, hogy bár időben megelőzte a korábban említett SDG-célok megalkotását, tudományos szempontból azonban számos kapcsolódás található, és közel sem tekinthető az ENSZ által kiadott új 2015-2030-as időszakra vonatkozó fenntartható fejlődési céloktól idegennek. A keretstratégia a Brundtland-bizottság által használt fenntartható fejlődési fogalmát tágabban és lazábban értelmezi, ezzel azonban nem elhagyva az eredeti jelentését és célját. A keretstratégia a fenntarthatóság értelmezését ekképp ragadja meg: „Az egyéni jó élet és a közjó biztositásának feltételeit az adott időpillanatban saját jólétét megteremtő generáció nem éli fel, nem meríti ki erőforrásait, hanem megfelelö mennyiségben és minőségben a következö generációk számára is megörzi, böviti

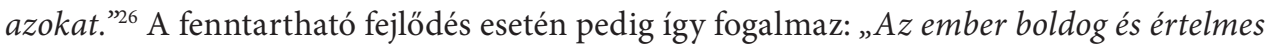
életvitelének elömozdítását és a közjó kiteljesitését célozza úgy, hogy az emberi tevékenységek a Föld környezeti eltartó-képessége szabta határokon belül maradnak, és a gyarapitható, fejleszthetö emberi társadalmi és gazdasági erőforrások terén gondoskodunk ezek megfelelö mennyiségi és minőségi állapotának a fenntartásáról, bövitéséről, illetve javitásáról. ’’7 A keretstratégiáról így elmondható, jelentős kibővítésen esett át a fenntarthatóság brundtlandi értelmezéséhez viszonyítva.

nagyobb hasonlóságot mutatja az európai uniós fenntartható fejlődési céljaival. Bővebben 1.: Kozma, Dorottya Edina: Comparative analysis of the sustainable development strategies and indicators of the V4. DETUROPE - The Central European Journal of Regional Development and Tourism, 11. (2019), 2. 101-120.

23 A továbbiakban NFFK, illetve keretstratégia alatt ugyanezen dokumentumot értjük.

24 Bartus Gábor (szerk.): Nemzeti Fenntartható Fejlődési Keretstratégia. Nemzeti Fenntartható Fejlődési Tanács Titkára, 2013b. 21.

25 Uo. 21-25.

26 Uo. 6.

27 Uo. 9 
A keretstratégia által kitűzött célok elérése és elemzése érdekében a KSH 2007 óta kétévente kiadja a fenntartható fejlődés indikátorainak teljesülését és változásának, alakulásának értékelését bemutató anyagot, amely tudományos szempontból az európai uniós iránymutatásokon alapul. ${ }^{28}$ Ezen elemzések a fenntarthatósági megközelítések közül illeszkednek az NFFK által vázolt szerkezetre, és ugyanazon négy dimenzió alapján dolgozzák ki azokat, vizsgálván a fenntartható fejlődés szempontjából releváns mutatók alakulását. Ez jelentős visszajelzésként és forrásként szolgál, valamint a Nemzeti Fenntartható Fejlődési Tanács által készített kutatások szerint szakmai szempontból igen részletesnek és versenyképesnek mondhatók nemzetközi összehasonlításban is, a megalkotásuk korai mivolta ellenére. ${ }^{29}$

A fenntarthatóságnak a hazai keretei mellett érdemes kitérni a terület különböző dimenzióira, értve ez alatt a fenntarthatósági elméletek megközelítéseit is. Az előbbiek során már említett hagyományos fenntarthatósági modell megközelítése leginkább az úgynevezett háromdimenziós vagy pilléres modellként ismeretes. Ez a Brundtland-bizottság által felállított fenntarthatósági meghatározásból eredeztethető, azonban számos tudományos kritika is érte ugyanezen felfogást. Több szerző kritikájának a középpontjában az áll, hogy a fenntarthatóság e három dimenziójára történő összpontosulást úgy értelmezi, hogy azok mind egyenlő, egyenrangú szerepet töltenek be. Ahogy Karcagi-Kováts is kiemeli, „a globális ökológiai válság csak a gazdaság és a társadalom, azaz a fenntarthatóságot veszélyeztető termelési minták és az életmód (illetve ennek fontos gazdasági eleme, a fogyasztási minták) radikális megváltoztatásával háritható el, akkor a fenntarthatóság három dimenziójának összefüggését helyesen használjuk". ${ }^{30}$ A kritikát azonban ott találja a háromdimenziós felfogásban a szerző, hogy több politikai indíttatású programban és a témához kapcsolható stratégiában a rövid és középtávú gazdasági és társadalmi kihívásokat az ökológiai és környezeti hosszú távú kihívásaival azonosként tünteti fel. Ennek következményeként olyan témakörök is bekerülhetnek a vizsgálódás tárgyába, amelyeknek a valódi fenntarthatóság szempontjából semmiféle kapcsolódási pontjuk nincs. ${ }^{31}$

A fenntarthatóság háromdimenziós felfogása és a Brundtland-bizottság által megalkotott széles körü definíció mellett megjelenik a tőkeelméleti fenntartható fejlődési elméleti iskola is, amely széles körü nemzetközi irodalommal bír, ${ }^{32}$ és számos magyar kutató

28 A módszertanról részletesebben 1.: Getting Messages across Using Indicators - A Handbook Based on Experiences from Assessing Sustainable Development Indicators. Luxembourg, Eurostat, Publication Office of the European Union, 2014.

29 Keller Tamás: Javaslat a fenntartható fejlödés társadalmi indikátorainak mérésére. Mühelytanulmányok - No. 13. Budapest, Nemzeti Fenntartható Fejlődési Tanács, 2012. 8., 20.

$30 \quad$ Karcagi-Kováts i. m. (5. 1j.) 36.

$31 \quad$ Uo. 36.

32 Részletesebben 1.: Pearce, David W. - R. Kerry Turner: Economics of Natural Resources and the Environment. Hemel Hempstead, Hertfordshire, Harvester Wheatsheaf, 1990.; Robert U. Ayres: On the Practical Limits to Substitution. Ecological Economics, 61. (2007), 1. 115-128.; Measuring Sustainable Development. New York and Geneva, United Nations Economic Commission for Europe, United Nations, 2009. 
is foglalkozott vele. ${ }^{33} \mathrm{E}$ felfogás a közgazdasági fejlődéselméletet veszi alapul, és annak analógiáját alkalmazza. A közgazdasági alapfelvetés, amely a fejlődés alapjaként a tőkét tekinti, a fenntartható fejlődés esetén is hasonlóképpen a tőkét teszi a középpontba, az úgynevezett teljes tőkét. Ez tulajdonképpen a tőke fogalmának a kiterjesztése oly módon, hogy az immáron az emberi tőkét vagy másként a humán tőkét (az emberi tudást, a tapasztalatokat és szerzett képességeket) is magában foglalja. ${ }^{34}$

E teóriából emelkedett ki a fenntarthatóság két további iskolája az 1990-es években, a gyenge és az erős fenntartható fejlődési kritérium, amelyek szorosan kapcsolódnak a háromdimenziós elképzeléshez. A gyenge fenntarthatósági kritérium jelentése abban lakozik, hogy a három dimenziót (környezet, társadalom és gazdaság) egymással egyenértékűnek kezeli, valamint arra koncentrál, hogy e három tőkéjének ne csökkenjen az összege a fejlesztések során. Ebből az elméleti iskolából adódik, hogy a három terület gyakorlatilag egymás helyettesítőjeként is müködhet, így tehát amennyiben az egyik pilléren csökkentést tapasztalunk, az elmélet hívői szerint elképzelhető, hogy a másik pilléren elért többletnövekedéssel egyensúlyban tartható az érték. Természetesen ebből fakadóan ennek az elméletnek a hiányosságai egyértelműek, hiszen az egyes pillérek képtelenek egy másik területnek a helyettesítésére. Ebből a kritikai elképzelésből eredeztethető az úgynevezett erős fenntarthatósági kritérium. Ezen elméleti iskola képviselőjeként Herman Daly úgy véli, vannak bizonyos környezeti korlátok, amelyeket önmagukban be kell tartani, miközben a környezetre nem közvetlenül, hanem annak alrendszereire vagyunk képesek hatást gyakorolni a gazdasági és a társadalmi folyamatokon keresztül. ${ }^{35}$

\section{A FENNTARTHATÓSÁGI INDIKÁTOROK BEMUTATÁSA}

A fentiekben ismertettük a fenntarthatóság konceptusa alakulásának rövid történetét és annak magyarországi kereteit és dimenzióit. Jelen tanulmány homlokterében a fenntarthatóság társadalmi oldala áll, amelynek keretében részletesebben foglalkozunk e terület mérésére alkalmas indikátorok és azok típusainak bemutatásával. Tekintettel arra, hogy ezeknek az indikátoroknak a magyarországi teljesülését kívánjuk ismertetni, így túlnyomó részt magyarországi adatokat bemutató forrásokra koncentrálunk.

A fenntarthatóság mérése érdekében kulcsfontosságú a helyes mutatók, illetve mutatórendszerek alkalmazása és vizsgálata. Az általánosan elfogadott közgazdasági alapvetések és mutatók hatékonyságának és célszerüségének megkérdőjelezése már az előző évszázad során kialakított, mára talán a legnépszerűbb piaci termelést mérő GDP-mutatónál

33 Részletesebben 1.: Szlávik János: Fenntartható környezet- és erőforrás-gazdálkodás. Budapest, KJK-KERSZÖV, 2005.; Kerekes Sándor: A fenntarthatóság közgazdasági értelmezése. In Bulla Miklós - Tamás Pál (szerk.): Fenntartható fejlödés Magyarországon - Jövöképek és forgatókönyvek. Budapest, Új Mandátum, 2006. 196-211.

34 Karcagi-Kováts i. m. (5. lj.) 38.

35 Fleischer Tamás: A fenntarthatóság fogalmáról. In Knoll Imre - Lakatos Péter (szerk.): Közszolgálat és fenntarthatóság. Budapest, Nemzeti Közszolgálati Egyetem, 2014a. 9-24. 18-20. 
felmerült. A GDP és a gazdasági növekedés mára már talán az egyik legtöbbet hangoztatott területté vált, ez azonban számos kritikát is hordozott magában, mivel nemcsak a fentiekben bemutatott környezeti mozgalmak hatására kerültek középpontba a növekedés korlátai, hanem egyre inkább felvetődött a kérdés, hogy valóban e módon a legjobb mérni a növekedésünket. ${ }^{36} \mathrm{Az}$ Amerikai Egyesült Államok története során a Hoover-adminisztrációhoz köthetjük a mai értelemben használatos GDP megalkotását, miután egy kormányzati és magánszakértőkből álló csoportot kongresszusi meghallgatásra hívtak, és alapvető gazdasági kérdésekre kívántak választ kapni a kérdezők. A meghallgatás nem zárult sikeresen, mivel a meghívottak nem találtak elegendő rendelkezésre álló, gazdasági méréshez alkalmas adatot a válaszadáshoz. Ezt követően 1932-ben kérte fel a Hoover-adminisztráció az akkori Kereskedelmi Minisztériumot azzal a céllal, hogy alkossa meg a nemzeti elszámolások egységes rendszerét. Simon Kuznets volt végül az, akinek a nevéhez köthető a mai GDP megalkotása. Miközben a mutató megszületését követően széleskörüen elterjedt, és máig használt mutatóról beszélünk, már a megalkotását követően aggályok merültek fel a felhasználhatóságát illetően. Maga Kuznets fogalmaz úgy saját munkájában, ${ }^{37}$ hogy "figyelemmel kell lenni a növekedés mennyisége és minemüsége közötti megkülönböztetésre, a költségek és a hozamok közöttire, a rövid és hosszú távú megfontolásokra" ${ }^{38}$ Ez tehát elindított egy elméleti kérdést, miszerint a meglévő, széles körben használt gazdasági mutatóink nem képesek teljes mértékben visszaadni azt, ami a valódi fejlődésünk és növekedésünk fenntartásához elengedhetetlen. A különböző fenntarthatósági elméletek éppen ezt kívánják megragadni, hogy a minket körülvevő ökológiai rendszer összefüggésében és végességét figyelembe véve vizsgálja a növekedésünket. A növekedés és fejlődés valódi mivoltával, valamint azzal, hogy a társadalom szempontjából hogyan lennénk képesek jobban mérni e folyamatokat, számos tudományos diskurzus foglalkozik. Az egyik kiemelkedő jelentőségü épp a 2008-2009-es globális pénzügyi válság idején Nicholas Sarkozy által felállított bizottság. E kezdeményezésben nemzetközileg elismert közgazdászok részvételével létrejött az ún. Stiglitz-Sen-Fitoussi-jelentés, ${ }^{39}$ amelyben a korábban felvetett GDP-vel szemben támasztott kérdéseket vizsgálták, és próbáltak kidolgozni egy olyan rendszert, amely jobban képes a jólétnek és a társadalmi elörehaladásnak a mérését megragadni, miközben a környezeti terheléseket is beemeli a rendszerbe. A bizottság a pénzügyi válság közepén részletekbe menően vizsgálta annak kérdését, hogy milyen pótlólagos adatok, mutatók szükségesek a jelenleg ismeretes GDP kiegészítéséhez. A fenntarthatóság és a környezet kérdései szintén fontos szerepet kaptak a felvetésükben, amelynek végességét és változásait indokoltnak tartották beemelni az újonnan kialakított mutatók közé.

36 A GDP-mutató esetén fontosnak tartjuk kiemelni, hogy célja szerint csak a gazdasági tevékenység pénzben mérésére koncentrál, így nem lehet rajta számon kérni a környezeti és társadalmi összefüggések kimutathatóságát. Vizsgálódási területünk szempontjából a fenntarthatóság oldaláról kívánjuk kiemelni a GDP korlátait.

${ }^{37}$ Részletesebben 1.: Simon Kuznets: How to Judge Quality. Washington, D.C.: The New Republic, 1962.

38 Szigeti Cecília: Az ökolábnyom és egyéb fenntarthatósági indikátorok mérési tartományának értelmezése. Journal of Central European Green Innovation, 3. (2015), 1. 49-68. 51.

39 Részletesebben 1.: Joseph Stiglitz - Amartya Sen - Jean-Paul Fitoussi: Report by the Commission on the Measurement of Economic Performance and Social Progress. 2009. 
A kérdés aktualitásáról megosztó véleményeket találni, hiszen problematikus a meglévő mutatók helyettesíthetősége. A fenntarthatósági elveket követők és kutatók többsége úgy véli, a fenntarthatóságot jobban megragadó indikátorkészlettel lehetne e kérdést feloldani. A fenntarthatóságot övező tudományos diskurzus elméleti megközelítése mellett az indikátorokat övezi talán a legnagyobb figyelem. ${ }^{40} \mathrm{~A}$ fenntarthatóság fogalmi kereteivel - ahogy a korábbiakban csak részletében mutattunk rá - valójában jelentős szakirodalmi bázis foglalkozik. Ugyanakkor az indikátorokat vizsgálva megjegyzendő, hogy a fenntarthatóság mérésének tisztázása jelenleg is e terület tudományos érdeklődésének középpontjában áll. Valójában a kérdés az, amit 2008-ban a Stiglitz-Sen-Fitoussi-féle jelentés is központi problémaként vizsgált, miszerint mivel és hogyan tudnánk felcserélni a meglévő mutatóinkat a társadalmi fejlődés jobb mérése érdekében (esetünkben ez a fenntarthatóság kapcsán vizsgálandó). A helyes indikátor(ok) felkutatása érdekében röviden térjünk ki a már meglévőkre, és vizsgáljuk meg azok relevanciáját.

$\mathrm{Az}$ indikátorok konceptusának tartalma kapcsán Havasi Éva találóan ekképpen fogalmaz: „Ha arra lennénk kíváncsiak, hogy fúj-e a szél vagy sem, akkor a fü, vagy a fa "hajladozása", operacionalizálva: dölésszögének megváltozása, megfelelo" indikátornak bizonyulna. Ráadásul a szél a maga valójában láthatatlan, megfoghatatlan, de a füszálon keresztül megragadhatóvá válik. Az indikátorok szerepe is hasonló a statisztikában. Természetesen egy elhajló füszál, vagy fa koronájának hajladozása érdeklödéstöl függően sokféle jelentéstartalmat hordozhat. Van, akinek azt jelenti, hogy sapkát kell vennie, ha kimegy az utcára, másoknak azt, hogy be kell hozniuk a virágokat a teraszról, mert az erös széltöl elpusztulnak a friss hajtások. Az indikátorok jelentése attól függ, hogy kik vagyunk, és mit akarunk. ${ }^{{ }^{311}} \mathrm{Az}$ indikátorok tehát rendkívül jól képesek jelezni számunkra a változás mértékét, illetve irányát, feltéve - és ez az egyik kulcsfontosságú elemünk a vizsgálódáskor - ha tudjuk, hogy mit szeretnénk mérni és hogyan. A szerző egy egyszerü példán keresztül szemléletesen bemutatta, hogy gyakorlatilag ugyanígy mérhetjük a különböző társadalmi, gazdasági vagy akár környezeti, komplex rendszereknek a rendszerszintü összefüggéseit is.

$\mathrm{Az}$ indikátoroknak tehát kulcsfontosságú szerepük van abban, hogy a statisztikai adatokként megjelenő információmennyiségben eligazodhassunk, valamint egy adott jelenségre vonatkozóan egyszerüsíteni legyünk képesek rendkívül összetett jelenségeket

40 A fenntarthatósági indikátorok elméleti hátteréről bővebben 1.: Sepehr Hendiani - Morteza Bagherpour: Development of Sustainability Index Using Z-Numbers: A New Possibilistic Hierarchial Model in the Context of Z-information. Environment, Development and Sustainability, 22. (2020), 7. 6077-6109.; Simon Bell - Stephen Morse: Sustainability Indicators Past and Present: What Next? Sustainability, 10, (2018), 5. 1688.; Nolam Lior - Mirjana Radovanović - Sanja Filipović: Comparing Sustainable Development Measurement Based on Different Priorities: Sustainable Development Goals, Economics, and Humal Well-Being - Southeast Europe Case. Sustainability Science, 13. (2018), 4. 973-1000.; Cagatay Tasdemir - Rado Gazo - Henry J. Queseda: Sustainability Benchmarking Tool (SBT): Theoretical and Conceptual Model Proposition of a Composite Framework. Environment, Development and Sustainability, 22. (2020), 7. 6755-6797.; Maria Kravchenko - Daniela C. A. Pigosso - Tim C. McAloone: A Procedure to Support Systematic Selection of Leading Indicators for Sustanability Performance Measurement of Circular Economy Initiatives. Sustainability, 12. (2020), 3. 951.

${ }^{41}$ Havasi Éva: Az indikátorok, indikátorrendszerek jellemzői és statisztikai követelményei. Statisztikai Szemle, 85. (2007), 8. 677-689. 678 
és folyamatokat. A fenntarthatóság mérésekor kiemelkedő szerepük van az előbbiekből kifolyólag a folyamat mérésére alkalmas mutatóknak. Az indikátorok vizsgálata tehát egy adott társadalmi, gazdasági vagy környezeti rendszer változását is jól mérheti. Fontos azonban a téma vizsgálatakor első körben kitérni arra, hogy miként alkotjuk meg azokat a fogalmakat, amelyeket vizsgálni kívánunk. A fenntarthatóság különböző oldalait bemutató indikátorok vizsgálata során lényeges kiemelnünk e ponton Karcagi-Kováts ${ }^{42}$ és Bartus ${ }^{43}$ megállapításait, miszerint szoros kapcsolat van a fenntarthatóság fogalma és annak mérésére kialakított indikátorok között. E tudományos feltevést látjuk érvényesülni számos fenntarthatósági mutató esetén, mivel azok felhasználási célja meghatározza azt, miként alakítjuk ki e fogalmakat, milyen változásokat képesek azok kimutatni.

A fenntarthatósági indikátorok bemutatása előtt fontosnak tartjuk röviden kitérni az általánosságban vett indikátorok osztályozására és különböző felosztásaikra, a teljesebb kép érdekében. Ahogyan azt Havasi is bemutatja a tanulmányában, ${ }^{44}$ az indikátorok összetettsége alapján lehetnek egyszerü vagy összetett indikátorok. Az egyszerü indikátorok közé tartozik például a szegénységi ráta, miközben az összetett mutatók közé sorolhatjuk a GDP-mutatót. Az összetett indikátorok között emellett elkülöníthetünk aggregált (összegző), illetve összetett (kompozit) vagy integrált indikátorokat. Az összetett indikátorok esetén kiemelnénk az úgynevezett bontott indikátort (decoupling), amelynek lényege a megbontásban, illetve „szétszedésben” található. Ezzel - Havasi példája alapján - jól tudunk mérni olyan területeken, ahol például gazdasági növekedést akarunk elérni, miközben csökkenteni akarjuk az energiafogyasztást. Egy másik nagyon fontos megközelítése az indikátoroknak az úgynevezett rendszerbe foglalt indikátorok. Ezen belül tematikus, vezetö- vagy kulcsindikátorokat különíthetünk el. Mivel a legfontosabb indikátorok nem önmagukban állnak, így ahogy a korábbiakban is utaltunk már rá, fontos őket rendszer összefüggéseiben vizsgálni, ezt teszik lehetővé az utóbb felsorolt indikátortípusok. Területi érvényességüket tekintve továbbá vizsgálhatnak területi, regionális adatokat vagy nemzeti területet, illetve nemzetközi szintü adatokat is.

$\mathrm{Az}$ indikátoroknak mindemellett számos egyéb feloszthatósági és mérhetőségi bontása különböztethető meg, azonban a terjedelmi korlátok következtében jelen tanulmányunkban sokkal inkább a fenntarthatósági indikátorokra koncentrálunk, amelyeket a következőkben foglalunk össze.

\section{1. Összetett mutatók a GDP kiegészítésére}

A fentiekben bemutatott GDP-mutatószámnak a korlátait kiküszöbölni kívánó törekvések során merültek fel olyan mutatók, amelyekkel a meglévő mutatóink kibővítését tudnánk

Karcagi-Kováts i. m. (5. lj.) 183.

43 Bartus Gábor: A fenntartható fejlődés fogalom értelmezésének hatása az indikátorok kiválasztására. Statisztikai Szemle, 95. (2013a), 8-9. 842-869. 857.

44 Havasi i. m. (41. lj.) 683-686. 
elérni és így bevonni a vizsgálódásba olyan területeket, amelyek kiemelt fontosságúak. Összefoglalóan összegezhetjük e mutatókat úgy, hogy a gyakorlatban kívánjuk megragadni a GDP háttérintézményét felhasználva egyéb, külsőnek nevezhető nem-piaci tényező(ke)t. E folyamatnak a lényege abban keresendő, hogy megpróbálja internalizálni a különböző külső tényezőket a gazdasági dimenzió terén. ${ }^{45}$ Erre születtek meg az úgynevezett összetett mutatók, amelyeket a következőkben röviden ismertetünk.

$\mathrm{Az}$ egyik legelső GDP-kiegészítésre szolgáló mutató a Measure of Economic Welfare (MEW) index megalkotása volt. A MEW a GDP által a piaci termelésre fókuszáló mutatóhoz kívánja adni a jólét mérését, amelyet a szabadidő értéke mellett a nem-fizetett tevékenységek beemelésével kívánja megragadni, levonva belőle a létrejött környezeti károk értékét. Mindezen törekvések célja az volt, hogy a jólétet a GDP-nél jobban ki tudják mutatni és mérni, azonban a legnagyobb hiányossága továbbra is az, hogy pénzben kifejezhető értékekre fókuszál. ${ }^{46}$

1989-ben azonban egy újabb mutatóval állt elö Daly és Cobb. ${ }^{47}$ Megalkották az Index of Sustainable Economic Welfare (ISEW-) indexet, amely szintén a jólét mérését kívánta megragadni, azonban akképpen dolgozták ki, hogy bizonyos tételeket, amelyek nem szolgálják a jólétet, le kell vonni a mutató végösszegéből.

A fenntarthatósághoz köthető indikátorok vizsgálatakor kiemelhetjük továbbá a valódi fejlődést (Genuine Progress Indicator - GPI), a tényleges megtakarítás (Genuine Saving/ Adjusted Net Saving - GS), valamint a jó élet (Well-being Index - WI) mutatóját. Ezen indexek szintén a GDP kiegészítésére vagy továbbfejlesztésére koncentrálnak. Bartus tanulmányában ${ }^{48}$ a GDP-t helyettesítő, valamint kiegészítő mutatók esetén külön kiemeli a tucatnyi lehetséges index közül a tényleges megtakarítás indexét, amely a közgazdasági értelemben vett fenntarthatóság szempontjából a legjobban közelíti meg a fenntarthatóság elvét. Az egyes indexek közötti helyettesíthetőségre mutat rá az, hogy amennyiben egy országot vagy társadalmat vizsgálunk - attól függően melyik mutatóval vizsgáljuk -, lehetséges, hogy míg egyik tekintetében nagyon jól teljesít a fenntarthatóság szempontjából, egy másik esetén viszont akár a legrosszabban, teljesen fenntarthatatlanul teljesít. ${ }^{49}$

\subsection{Sokdimenziós fenntarthatósági mutatók}

Az összetett mutatók mellett egy másik nagy kategóriát képeznek a sokdimenziós fenntarthatósági mutatók. Ezen elképzelések a tudományos viták központi elemét képezik, hiszen ezek - a korábban említett indexekkel ellentétben - nem a kiegészítést, hanem a hagyományosan használt mutatóink helyettesítését kívánják elérni.

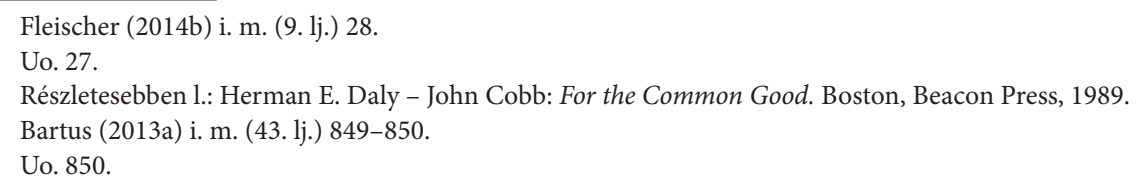


Az egyik első ilyen kezdeményezés, amelyet a mai napig jelentős figyelmet övez, az ENSZ keretein belül született meg 1990-ben, Mahbub ul Haq és Amartya Sen munkája alapján. $\mathrm{Az}$ általuk létrehozott humán fejlesztési index (Human Development Indicator - HDI) az egészségi állapot, iskolázottság és a gazdagság ötvözeteként vizsgálja és méri a fejlettséget, miközben a környezeti összefüggéseket nem emeli be a vizsgálódási körébe. A HDI alakulását a mai napig az ENSZ minden évben kiadott jelentéseiben vizsgálja. ${ }^{50}$

A GDP helyettesítésére dolgozták ki a Yale és Columbia Egyetem kutatói az Európai Unió (EU) szakértőivel együttmüködésben a Környezeti Teljesítmény Indexet (Environmental Performance Index - EPI), amely korábban a Környezetvédelmi Fenntarthatósági Indexként (Environmental Sustainability Index - ESI) volt ismeretes. E mutató a környezetvédelmet, a közegészségügyet és az ökoszisztéma egészségét kívánja megragadni és számszerüsíteni. A mutató 0 és 100 közötti értéket vehet fel, és minél nagyobb az értéke a mérőszámnak, annál kedvezőbb adatokat mutat.

A következő mutató a Boldog Bolygó Index (Happy Planet Index - HPI), amelyet a New Economic Foundation számításai alapján ismerhettünk meg. Ez gyakorlatilag az Ökológiai Lábnyom (Ecological Footprint) mutatóra támaszkodik, mivel a várható élettartam, az elégedettség az élettel és maga az ökológiai lábnyom értéke mellett, az életminőséget meghatározó objektív és szubjektív mutatókkal is kiegészíti. ${ }^{51} \mathrm{Az}$ előzőhöz hasonlóan e mutató is 0 és 100 közötti értéket vehet fel, és hasonlóan a magasabb elért pont mutatja a kedvezőbb adatot.

Talán az egyik legtöbbet használt mutató mindemellett az ökológiai lábnyom elnevezésű mutató, amely azt fejezi ki, hogy az emberi társadalomnak egy adott technikai fejlettség mellett milyen mennyiségü produktív földterületre van szüksége ahhoz, hogy az önmaga által kitermelt hulladékot elnyelje, és a saját létét fenntartsa. ${ }^{52} \mathrm{Az}$ ökológiai lábnyom az elözőkben felsorolt mérőszámok által körülírt jelenségeknél annyival megy tovább, hogy a földi tevékenyégeinknek a kifejtett hatását képes mérni és arányosítani, így pedig könynyen összehasonlíthatóvá válnak a Föld országai. Az ökológiai lábnyom megkönnyíti annak a mérését, hogy az emberi igényeknek a kielégítése milyen terheléssel jár az ökoszisztéma szemszögéből. A mutató megalkotói ${ }^{53}$ nemcsak a tevékenységek különböző hatásait vizsgálták, hanem egész fogalomrendszert alkottak meg a rendszer jobb megragadásához. Így alkották meg a földhasználati módot és a globális hektár (gha) fogalmát mint mértékegységet. Míg előbbi a Földön található összes biológiailag termékeny földterületet és vízfelületet foglalja magában, az utóbbi a különböző földterületek összehasonlítását lehetővé tevő egységes átlagos hektárt jelöli (amelyeknek az összege megközelítőleg 12 milliárd földi hektárt tesz ki, és összegük megegyezik a biológiailag termékeny földterületekkel).

Részletesebben 1.: Human Development Report 2019. New York, United Nations Development Programme, 2019.

Szigeti i. m. (38. lj.) 55 .

Uo. 55.

Részletesebben 1.: Mathis Wackernagel - William Rees: Our Ecological Footspring: Reducing Human Impact on the Earth. Philadelphia, PA, New Society Publishers, 1996. 
E két fogalom és a mutató saját számolási módszertanának felhasználásával ${ }^{54}$ következtetni lehet a biokapacitás figyelembevétele mellett ${ }^{55}$ a Földünk eltartóképességére. Ez az indikátor gyakorlatilag megmutatja, hogy egy adott terület milyen mértékű maximális népességet képest ellátni. Az elmélet megalkotása mellett a kutatók napjainkig is minden évben elkészítik az úgynevezett nemzeti lábnyomra vonatkozó kutatásaikat, ahol egy adott ország ökológiai lábnyomát mutatják be, és hasonlítják össze a világ összes többi országával.

Kiemelendő mindemellett az OECD által előállított sokdimenziós mutató, a Better Life Index (BLI). Ennek érdekessége sokszínűségében és módosíthatóságában rejlik. A mutató 11 különböző területet ötvöz magában, úgymint: a háztartást, a jövedelmet, a munkát, a közösséget, az oktatást, a környezetet, az állampolgári szerepvállalást, az egészséget, az élettel való elégedettséget, a biztonságot és végül a munka-élet egyensúlyát. A mutató sajátosságaként kiemelhető, hogy annak felhasználója képes arra, hogy a 11 különböző terület között fontossági sorrendet állítson fel, illetve súlyozza az egyes területeket a mutatón belüli területek priorizálása érdekében. Elemzői szemszögből ez a felhasználhatóságot tekintve úgy változtat, hogy nincs egy konkrét rangsor, amely így kialakulhat az országok között a súlyozás miatt, hiszen annak függvényében alakul át, és így nem lehet abszolút sorrendet megállapítani.

A fellelhető fenntarthatósági indikátorok összességének bemutatása jóval meghaladná jelen tanulmány terjedelmi korlátait. A fentiekben kiválasztott indikátorokat a fenntarthatóság komplex mutatóinak bemutatása érdekében, szakirodalmi jelentőségük, valamint népszerüségük miatt választottuk ki. Az Ökológiai Lábnyom és a BLI kivételével a felsorolt mutatók (MEW, ISEW, GP, GPI, HPI, HDI) esetén, amellett hogy a fenntarthatóságnak ama szegmensét, hogy véges készletek vesznek körül minket a földi létünk során, jól megragadják, azonban az egyik legnagyobb kritika, amivel illetik e mutatókat, abban rejlik, hogy továbbra is pénzben próbálják internalizálni a külső véges tényezőket, amely mértékegység végső soron végtelennek tekinthető.

A vállalati fenntarthatóság kapcsán kiemelendő a Dow Jones Sustainability Index (DJSI), amelyet 1999-től használnak a vállalatok esetében azok fenntartható teljesítményének mérésére, ${ }^{56}$ amely olyan „üzleti szemlélet, mely úgy növeli a részvényesi értéket, hogy kiaknázza a lehetőségeket és menedzseli a kockázatokat, melyek a gazdasági, társadalmi és környezeti fejlesztésekben rejlenek". ${ }^{57}$ Vizsgálják az elemzés során a társadalmi, környezeti és gazdasági szempontjait a vállalatnak, és értékelik azt. Ezek keretében kitérnek a munkaügyi gyakorlatok kérdésköre mellett az éghajlatváltozás mérséklésére, a brandingre, az ellátási lánc szabványaira, továbbá a kockázatmenedzsmentre is. A DJSI mérési index

54 Összefoglalva 1.: Fleischer (2014b) i. m. (9. 1j.) 34-35.

55 A biokapacitás a technológiai lehetőségek mellett a hasznos biológiai produktumot és szén-dioxid-mennyiséget elnyelő képesség mutatója.

56 Berkesné Rodek Nóra: CSR EMAT - A vállalatok társadalmi felelösségvállalásának kiválósági menedzsment és értékelési eszköze. Doktori értekezés. Veszprém, Pannon Egyetem, Gazdálkodás- és Szervezéstudományok Doktori Iskola, 2018. 91.

57 David Vogel: The Market for Virtue - The Potential and Limits of Corporate Social Responsibility. Washington, D.C.: Brookings Institution Press, 2006. 2. 
évente értékeli azon vállalatok körét - a fenntartható fejlődés három alappillére (környezet, társadalom, gazdaság) alapján -, amelyek elkötelezettek e módszer alkalmazása iránt, mindezt a fenntartható fejlődés három alappillére szerint. ${ }^{58}$ Kiemelendő a módszer kapcsán, hogy amennyiben egy vállalat a DJSI adatbázisába bekerül, onnantól kezdve a vállalat médiamegjelenése napi szinten nyomon követhetőek. Hangsúlyozandó, hogy negatív kritika esetén a tagok listájából kizárják az érintett vállalatot, példának okáért említendő az emberi jogok megsértése, a kereskedelmi gyakorlatot, illetve a vállalati tevékenységet ért súlyos kritika stb. ${ }^{59}$

A társadalmi befektetés megtérülése, avagy Social Return On Investment (SROI) egy mérési keretrendszer. Lényege abban ragadható meg, hogy meghatározott alapelvek mentén a hagyományos könyvelésnek a részét nem képező értékeket méri úgy, mint környezeti vagy éppen társadalmi értékek. Az SROI a társadalom szempontjából hozzáadott értékkel bíró változásokat hivatott mérni gazdasági, társadalmi, környezeti szempontból, és a változást magát értékeli. Rámutat arra, mekkora mértékủ megtérülést eredményeznek e területeken a befektetések. Az SROI vonatkozásában a 3:1 arány azt mutatja meg, miszerint például $1 £$ befektetés $3 £$ társadalmi vagy környezeti értéket eredményez. ${ }^{60} \mathrm{Az}$ SROInak két különböző típusa ismeretes: az értékelő, valamint az előrejelző. Az értékelő a tényleges, már megvalósult eredményekre fókuszál; míg az előrejelző azt mutatja meg, hogy ha az elöre tervezettek szerint alakulnak az egyes tevékenységek és e tevékenységek eredményei, akkor milyen mennyiségű társadalmi érték keletkezik. ${ }^{61}$

A vállalatok elkezdtek fenntarthatósági jelentéseket készíteni az 1970-es években, ${ }^{62}$ amelyek egyfajta „feedbackként” funkcionáltak akképpen, hogy az érintettek tudomást szerezhettek arról, hogy a vállalatok miképpen kezeltek egyes társadalmi problémákat. ${ }^{63} \mathrm{Hang}$ súlyozandó, hogy e jelentések a vállalatok önként vállalt tevékenységei közé tartoznak, ellentétben például a pénzügyi beszámolók kötelező elkészítésével. A fenntarthatósági jelentés egyfajta tükörként funkcionál a cég számára saját működésével kapcsolatban, így az nem csupán a vállalat tevékenységét külvilág irányába történő megnyilvánulását szolgálja. ${ }^{64}$

A Global Reporting Initiative (GRI) azzal a szándékkal jött létre 1997-ben, hogy a fenntarthatósági jelentések készítésének egyfajta egységes keretet biztosítson. Ennek megfelelően egy jól strukturált, könnyen kezelhető jelentéskészítési rendszer. Az első jelentéstételi ajánlás 2000-ben jelent meg. Rá két évre, 2002-ben, önálló szervezetként megalakult

\footnotetext{
Berkesné Rodek i. m. (56. 1j.) 91.

59 Részletesebben 1.: Suzanne Benn - Dianne Bolton: CSR iránytü - alapfogalmak, kulcskoncepciók. Budapest, Atlantis Press Kft., 2015.

60 Berkesné Rodek i. m. (56. lj.) 92.

61 www.socialvalueuk.org/resources/sroi-guide/ (A letöltés dátuma: 2020. 06. 01.)

62 Részletesebben 1.: Dan H. Bauer - Raymond A. Fenn: The Corporate Social Audit. New York, Russell Sage Foundation, 1972.

63 Berkesné Rodek i. m. (56. lj.) 73.

64 Részletesebben 1.: Radácsi Lajos: A társadalmi felelösségvállalás könyve. 25 magyarországi vállalat rövid CSR jelentése. Budapest, Braun \& Partners Kft., 2008.
} 
a GRI, amszterdami székhellyel, és jelenleg az ENSZ égisze alatt müködik. A GRI egy olyan független civil szervezet, amelynek célja egy nemzetközileg elfogadott jelentéskészítési irányelv elkészítése és folyamatos fejlesztése; ekképpen biztosítva a közölt információk átlátható, időszerű, ellenőrizhető, összehasonlítható, hiteles, pontos voltát. ${ }^{65}$ A GRI három szintjét különböztethetjük meg: „A”, „B”, és „C” szinteket, ahol „A” a legszigorúbb, „B” a mérsékeltebb, „C” pedig a kötetlenebb szintet mutatja. A felhasználók e preferenciák mentén választhatják meg, milyen szintű jelentést kívánnak készíteni. ${ }^{66}$

\section{A FENNTARTHATÓSÁG TÁRSADALOMPOLITIKAI INDIKÁTORAI ÉS AZOK TELJESÜLÉSE MAGYARORSZÁGON}

Jelen tanulmány kiemelten kezelt területe a fenntarthatóság társadalmi oldalról való megközelítésének vizsgálata. A korábbiakban bemutatott fenntarthatóság magyar keretei közt a NFFK fenntarthatósági megközelítését tekintve jól elkülöníthetően jelenik meg a társadalmi területe a fenntartható fejlődésnek. A fenntarthatóság teljes megvalósítása, illetve annak minél inkább gyakorlatba történő átültetése esetén elengedhetetlennek tekinthető, hogy a fenntarthatóság társadalmi oldala mellett a gazdasági és környezeti pillérek, valamint az emberi erőforrások egyenlő módon történő teljesülése valósuljon meg, hiszen jelentős hatással vannak egymásra. A fenntartható fejlődéshez történő hozzájárulások kulcsfontosságú szerepet játszanak egy társadalomban, hiszen elősegítik annak folyamatát.

\subsection{A társadalmi fenntarthatóság indikátorai}

A korábbiak során bemutattuk a fenntarthatóság elméleti megközelítéseit, mindezek között azonban nincs olyan kiemelhető elmélet, amely kizárólagos vagy nagyobb figyelmet szentelne a fenntarthatóság társadalmi oldalának. Ugyanez elmondható a szakirodalom vizsgálatakor, miszerint egész egyszerűen nincs olyasfajta, általánosan elfogadott mutató vagy mutatórendszer, amely lényegében kizárólag ezt ragadná meg. Magyarország esetén a Központi Statisztikai Hivatal (KSH) készít rendszeresen saját, 2007 óta kétévente megjelenő, fenntartható fejlődési indikátorok vizsgálatára irányuló kiadványt, amelyben külön foglalkozik a társadalmi fenntarthatóságra javasolt indikátorkészletének monitorozásával. E mutatókészletnek a változásával a későbbiek során foglalkozunk részletesen.

A társadalmi fenntarthatóság mérésére rendelkezésre álló elméleti hiánypótlásra tesz kísérletet a Nemzeti Fenntartható Fejlődési Tanács 2011-ben közzétett tanulmánya, amely részletesen foglalkozik a fenntarthatóság társadalmi oldalával, és kísérletet tesz az alkalmas

65 Berkesné Rodek i. m. (56. lj.) 74.; Részletesebben 1.: Braun Róbert: Vállalati társadalmi felelösségvállalás. A vállalatok politikája. Budapest, Akadémiai Kiadó, 2015.

66 Berkesné Rodek i. m. (56. lj.) 74.; Részletesebben 1.: Radácsi i. m. (64. lj.) 
mérési rendszerének kidolgozására ${ }^{67} \mathrm{E}$ tanulmány a fenntarthatóság társadalmi oldalának kutatási területén történő elméleti megalapozását kívánja pótolni és gyakorlati rendszerét megalkotni, valamint javaslatokat tenni a mérhetőségére alkalmas rendszer kialakítására. Megközelítésük három lényeges elemből tevődik össze: a társadalmi kohézió szerepéből, a korrupció mértékéből és a fenntartható fejlődés emberi tényezőiből, amelyet a kultúra mérésére is alkalmaznak. A megalkotásuk során olyan elemeket kell megvizsgálni és mérlegelni, hogy társadalmi tekintetben melyek azok az értékek, amelyeket fenntarthatósági szempontból a társadalom esetén kiemelendőnek tekintünk, valamint miként ragadjuk meg annak mérését. A társadalmi fenntarthatósági indikátoroknak a társadalom hoszszan tartó fennmaradását eredményezö értékekre kell összpontosítaniuk, de mivel nincs egységesen kidolgozott rendszere ennek, így két különböző megközelítést alkalmaznak a területet vizsgáló szakirodalmi források. A KSH a fenntartható fejlődés indikátorainak monitorozására készített kiadványában ${ }^{68}$ a társadalmi fenntarthatóságot az anyagi biztonság, a bizalom és társadalmi aktivitás három fő területre osztva 13 jelzőszámmal vizsgálja a folyamatokat, és teszi hosszú távon összehasonlíthatóvá változásukat. A 13 külön mutató a három fő területre osztva a következőkre fókuszál. Az anyagi biztonság vizsgálata során a szegénységi kockázat, a jövedelemeloszlás egyenlőtlensége, a háztartások anyagi helyzete, az önfoglalkoztatók, illetve atipikus foglalkoztatás aránya és a gyermekek óvodai és bölcsődei elhelyezési lehetőségei vannak számszerüsítve. A bizalom esetén az általános bizalom, a személyes kapcsolati háló és a lakosság jogrendszerbe vetett bizalma kerül vizsgálatra. A társadalmi aktivitást a nonprofit szervezetek, az önkéntes munkát végzők számán, a parlamenti választásokon történő részvételi arányon és az e-kormányzás elérhetőségén keresztül kívánja megragadni. A társadalmi erőforrásoknak e formában történő vizsgálatának felosztását a KSH a korábbi kiadványaiban is következetesen ezek alapján vizsgálta. Összevetve az NFFT által kidolgozott javaslatokkal, több eltérést is találunk.

Az NFFT által kiadott tanulmány egy saját mérési rendszert dolgozott ki, és sokkal inkább a társadalmi fenntarthatóság mögött lévő elméleti háttér megalapozására és finomítására hívta fel a figyelmet ahelyett, hogy egyetlen indexszám vagy indikátorkészlet kimunkálását tegye meg. ${ }^{69} \mathrm{~A}$ társadalmi fenntarthatóság tudományos szempontjait és elméleti oldalát is figyelembe vevő szakirodalom mindmáig kidolgozatlan maradt, holott a fontossága kiemelkedőnek tekinthető.

\subsection{A társadalmi fenntarthatóság hazai teljesülése}

Jelen fejezetben megvizsgáljuk a fenntarthatóság társadalmi oldalának mérésére elérhető legfrissebb indikátorkészletet és azok teljesülését. E fejezetben a KSH által 2019-ben

Részletesebben 1.: Keller i. m. (29. lj.)

68 Részletesebben 1.: Bóday Pál (szerk.): A fenntartható fejlődés indikátorai Magyarországon, 2018. Budapest, Központi Statisztikai Hivatal, 2019.

69 Keller i. m. (29. lj.) 10. 
publikált fenntartható fejlődés indikátorainak változását figyelemmel kísérő kiadványára támaszkodunk. ${ }^{70}$

A szegénységi kockázat indikátora az egyes korcsoportokban a szegénység esélyét mutatja meg úgy, hogy az adott korcsoportba tartozó szegények arányát viszonyítja az országos átlaghoz. A mutató esetén a medián jövedelem 60\%-a alatti jövedelemmel rendelkezőket definiáljuk szegényként. Az egynél nagyobb érték esetén a kategória tagjainak a szegénységi küszöb alá esése az átlagosnál nagyobb, míg az egynél kisebb esetén a kockázat az átlagosnál kisebb.

$\mathrm{Az}$ eltérő korosztályokban más és más következményekkel jár a szegénység. Gyermekkorban például az anyagi helyzet föleg a szülök jövedelmétől függ, ebben a korban kiemelten fontos a biztos anyagi háttér, hiszen az alapvető szükségletek kielégítése mellett a szociális és oktatásba való integrációt is jelentősen meghatározza a család keresete. A gyermekszegénységet számtalan országban, így Magyarországon is szociális intézkedésekkel csökkentik, hogy biztosítsák az egészségügyi, gondozási, fejlesztési és szociális szolgáltatásokhoz való hozzáférést. Ennek köszönhetően az elmúlt öt évben jelentős csökkenést figyelhettünk meg e korosztály szegénységi kockázatának mértékénél, az érték 2018-ra $1,2 \%$ alá csökkent. Az életkor előrehaladtával a szegénységi arány és kockázat egyaránt csökken. A 65 év felettiek szegénységi kockázata 2018-ban 0,8\% alatt volt, ami az ország jól felépített nyugdíjrendszerét igazolja. ${ }^{71}$

Jövedelemeloszlási egyenlőtlenség esetén az ekvivalens jövedelmek eloszlásában a felső és az alsó jövedelmi ötöd hányadáról beszélhetünk, tehát minél nagyobb az érték, annál nagyobb a bevételoldali egyenlőtlenség az adott területen. Mivel a nagy jövedelmi különbségek hosszú távon nem fenntarthatók, ezért fontos az állandó elemzésük és az ellenük tett intézkedések hatékonysága. A jövedelemeloszlást több dimenzióban is vizsgálhatjuk, például életkor és képzettség szerint, mi itt most a földrajzi tagolódásra, azon belül a Magyarországra jellemző értékekre térünk ki. Az S80/S20 néven is ismert indikátor hazánkban a 2008-as gazdasági válság után kissé megemelkedett, de 2014 óta az érték 4,2 körül stagnál, tehát stabilitásról beszélhetünk. Ez az érték megfelelő társadalmi viszonyokat jelent, a jövedelmi eltérések szűk skáláját. Az érték az Európai Unióra vonatkozóan 5, vagyis az európai társadalom leggazdagabb ötödének jövedelme ötszöröse a legszegényebb ötödének. Az indikátor nagysága, figyelembe véve a kelet-közép- és nyugat-európai országok közötti jövedelmi eltéréseket, még mindig nem tekinthető magasnak, de országunkénál nagyobb egyenlőtlenséggel jellemezhető a térség. ${ }^{72}$

A háztartások anyagi helyzetét a háztartások eladósodottsági rátájával jellemezhetjük, amely azt mutatja meg, hogy rendelkezésre álló jövedelmüknek hány százaléka az adott időszak bruttó hitelállománya. A családok által felvett hitelek nagyságát sok minden befolyásolhatja. Kiemelkedően fontos, hogy a polgárok pénzügyi edukáltsága megfelelő szintű legyen, így fel tudják mérni saját kockázatviselö képességüket, a különböző pénzügyi

\footnotetext{
Részletesebben ld.: Bóday i. m. (68. lj.) 76-101.

Uo. 76 .

Uo. 77.
} 
szolgáltatások előnyeit és hátrányait. Amennyiben ez fennáll, elkerülhető a nagyobb pénzügyi krízis, a magas számú nagy kockázattal járó befektetések nélkülözése révén. A magas számú, háztartások által felvett hitel alapvetően még nem jelent gazdasági problémát, hiszen sok esetben a kölcsön teremti meg a családok számára a fejlödés lehetőségét, a probléma inkább a magas kockázatú pénzügyi eszközökkel van. ${ }^{73}$

Magyarországon a háztartások eladósodottsági rátája 1998-ban volt a történelmi mélypontján, 6,2\%-os. Az értéket a 2000-es évek során és a 2010-es évek elején súlyosbította, hogy a devizaalapú hitelek nagyobb arányban növekedtek a forintalapú hiteleknél. A folyamatot azonban kormányzati beavatkozással sikerült visszafordítani, 2015-re az érték megközelítőleg a 2001-es szintre csökkent. A háztartások hiteleinek összességét tekintve elmondható, hogy 2011 óta folyamatosan csökken az összes jövedelemhez viszonyított aránya. A csökkenő tendencia valószínűleg a háztartások válság következtében is kialakult óvatosabb befektetési hangulatának köszönhetö. ${ }^{74}$

Az anyagi biztonságérzet számítását egy kérdőív segítségével mérik fel, amelyben a következő kérdést teszik fel: „Véleménye szerint hogyan tudja fedezni az Önök háztartása a szokásos kiadásokat?”. Az indikátor értéke megegyezik azoknak az arányával, akik a feltett kérdésre azt válaszolták, hogy nagy nehézségek árán tudják fedezni a szokásos kiadásaikat. A háztartások szubjektív véleményére azért van szükség, mert ez több társadalmi és gazdasági tendenciát is befolyásol. Amennyiben a háztartások úgy érzik, hogy biztos és elégséges jövedelemmel rendelkeznek, többet fogyasztanak. A háztartások fogyasztási kiadásai jelentős mértékben befolyásolják a gazdaság, így a GDP értékének növekedését, emellett a társadalom biztonságérzete magasabb életszínvonalhoz és magasabb szintű munkamorálhoz vezet, ami fenntarthatóbb társadalmi viszonyokat eredményez. ${ }^{75}$

Magyarországon azoknak az aránya, akik úgy érzik, hogy a mindennapi kiadások gondot okoznak számukra, magasabb az Európai Unió egész területére vonatkozó értéknél. Míg az EU-ban 2018-ban 7,5\% körül alakult az érték, addig Magyarország esetében ugyanebben az évben 12,1\%-ról beszélhetünk. Bár ez az érték viszonylag magas, a 2013 óta tartó folyamatos meredek csökkenés egy pozitív társadalmi folyamatra utal. ${ }^{76}$

A fenntartható fejlődés egyik legfontosabb momentuma a foglalkoztatottság, a munkanélküliség természetes rátájának fenntartása nemcsak a társadalomra, hanem a gazdaságra is jelentős hatással van. A foglalkoztatottságon belül vizsgálhatjuk az atipikus foglalkoztatottak számát, amely a modern társadalomban kiemelkedő relevanciával bír. A munkavégzés e típusa, amelybe fóként az önfoglalkoztatók, részmunkaidőben dolgozók és a határozott idejü szerződéssel foglalkoztatottak tartoznak, elösegítheti a foglalkoztatottság és a versenyképesség együttes növekedését, a munkahelyteremtés és a megfelelő munkakörülmények biztosítása mellett.

Bóday i. m. (68. lj.) 78 .

Uo. 78.

Uo. 79.

Uo. 79. 
Bizonyos arányok Magyarországon és az Európai Unió többi tagországában is egyaránt megfigyelhetők. Az önfoglalkoztatók között, akik a magyar 15 és 64 év közötti lakosságnak 9,9\%-át képezték 2018-ban, jelentősen magasabb a férfiak aránya, mint a nőké. Ellentétben ezzel, a részmunkaidőben dolgozók között nagyobb arányban találhatók nők. Megfigyelhető, hogy az önfoglalkoztatottak száma a 2000-es évek óta folyamatosan, de lassú mértékben csökkent, így egyre stabilabb pozíciót biztosítva a sokkal nagyobb biztonságot jelentő alkalmazotti formában történő foglalkoztatásnak. Ebből is látható, hogy a magyar befektetési és kockázatvállalási kedv tartósan alacsony. A részmunkaidőben dolgozók száma az elmúlt két évtizedben stagnált, csak a 2008-as gazdasági válság környékén figyelhető meg kisebb mértékü növekedés. Mindkét indikátor esetében elmondható, hogy magasabb arányuk a gazdaság nagyobb fokú rugalmasságához vezet, bár az egyének számára kisebb biztonságot nyújt a tipikus foglakoztatásnál. A részmunkaidőben foglalkoztatottak kapcsán külön megemlítendő, hogy az arány növekedése esetén fontos szerepet játszanak olyan anyák, akik a gyermekvállalás miatt csak részmunkaidőben térnek vissza dolgozni. Tehát a növekvő szint ebben a formában a társadalom magasabb életszínvonalára is utalhat. ${ }^{77}$

Fontos társadalmi mutató továbbá a bölcsődei és óvodai kihasználtság százalékos mutatói, hiszen egy egészségesen működő társadalomban elengedhetetlenek a gyermekek számára biztosított megfelelő szociális és gondozói körülmények. A gyermekek korai lemorzsolódása mellett, a felügyelet révén a szülők korábban tudnak újra munkába állni, ami számukra a gyermekvállalás által keletkezett költségek csökkentését, a társadalom számára pedig a humán tőke magasabb fokú kihasználtságát jelenti. Mivel a bölcsődei ellátás 2017. január 1-jétől jelentősen átalakult, ezért a korábbi adatokkal való összehasonlítás kevésbé releváns. Elmondható azonban, hogy a bölcsődei nevelés új formái, a családi bölcsőde, a munkahelyi bölcsőde és a mini bölcsőde hozzájárultak ahhoz, hogy a kisebb lakosszámú településeken is igénybe vehető legyen a szülők számára a 3 éves kor alatti gyerekek napközbeni gondozása. Így az országosan elérhetővé vált 47169 férőhelyen 44577 gyermek tudott részt venni bölcsődei nevelésben, ami 95\%-os kihasználtságot jelent. ${ }^{78}$

Az óvodai nevelésben 2018-ban a 3 és 5 év közötti gyerekek 92\%-a vett részt, ami kismértékű növekedést jelent az előző évhez képest. Mivel az elmúlt két évtizedben az óvodai nevelésben részt vevő gyermekek száma csökkent, míg az óvodai férőhelyek száma nőtt, így a kapacitás kihasználtsága 2000 és 2018 között 98\%-ról 86\%-ra csökkent. Ez alapvetően az egy gyerekre jutó óvodai nevelők számát tekintve kedvező, de gazdasági oldalról a kihasználtság csökkenése miatt kevésbé kívánatos tendencia. A településszerkezet és a régiók lakosszáma jelentősen befolyásolja a bölcsődei és óvodai férőhelyek kihasználtságát. Csongrád megyében például 100\% feletti a bölcsődei férőhely-kihasználtság, ezért itt kiemelkedően fontos az új bölcsődetípusok bevezetése. ${ }^{79}$

\footnotetext{
Bóday i. m. (68. lj.) 81-83.

Uo. $84-85$.

Uo. 85 .
} 
A társadalmi tőkét jellemezhetjük az általános bizalom indikátorával is, amely szintén a lakosság által kitöltött kérdőív alapján határozható meg. A válaszadók egy 0-tól 10 -ig terjedő skálán értékelik, hogy véleményük szerint mennyire lehet megbízni az emberekben. Magyarországon az indikátor 2015 óta 5-ön stagnál. ${ }^{80}$ Érdekes lehet azonban a különböző ismérvek szerinti megoszlást is vizsgálni. Általánosságban elmondható, hogy a kor és az emberek által érzett bizalom fordítottan arányos, vagyis a fiatalok pozitívabb jövőképpel rendelkeznek. A végzettség és az általános bizalom kapcsolatát vizsgálva kijelenthetö, hogy minél magasabb végzetséggel rendelkezik valaki, annál nagyobb a többi ember által érzett bizalma. A mutató területi eloszlás szerint az érték a kisebb városokban a legalacsonyabb: 4,8 és a megyei jogú városokban, valamint a községekben a legnagyobb: $5,2{ }^{81}$

A társadalom tagjainak egymás iránt érzett bizalma olyan kormányzati intézkedésektől függhet, mint a jogi szabályozás szigorúsága és a büncselekmények szankcionálása. Fontos a mutató megfelelő szinten tartása, hiszen a kielégítő bizalmi szint elengedhetetlen a piaci mechanizmusok működéséhez. Az indikátor értékének csökkenése a kor elörehaladtával negatív tapasztalatokra utal az élet során, fontos, hogy az emberek fiatalkorban kialakult bizalmát embertársaik iránt különböző intézkedésekkel életük végéig fenn tudjuk tartani. ${ }^{82}$

A bizalom egy másik formája a lakosság jogrendszerbe vetett bizalma, ezt a mutatót hasonló adatfelvételi módszerrel vizsgálják, 0-tól 10-ig terjedő skálán. A nemzeti intézmények, a jogrendszer a politikai rendszer és a rendőrség által érzett bizalom azért fontos, mert ezek az intézmények vannak leginkább hatással az ország hosszú távú jövőjére. Ha a társadalom úgy érzékeli, hogy védve van ezen intézmények által, és emellett eljárásaikat igazságosnak tartja, akkor maga is tisztességesebben jár el bizonyos esetekben.

Magyarországon 2018-ban a három intézmény közül a legmagasabb a rendőrségbe vetett bizalom 6\%-kal, ezt követi a jogrendszerbe vetett bizalom, majd végül a politikai rendszerbe vetett bizalom..$^{83}$

A bizalom mellett fontos megvizsgálunk az emberek kapcsolati hálóját. Egy egészségesen müködő társadalomban az embereknek kiegyensúlyozott családi és közösségi élete van. Magyarországon a személyes kapcsolati háló kiterjedtségét a 16 éven felüli lakosság körében vizsgálják úgy, hogy felmérik azok arányát, akiknek van olyan ismerőse, akivel a személyes ügyeiket meg tudják vitatni. Az érték csúcspontja 2013-ban 93,3\% volt, ami kimagaslóan jónak tekinthető a régió többi országához képest. 2013-ban 3,4\% vélte a 16 vagy annál idősebbek körében, hogy nem tudja megosztani a személyes dolgait senkivel. 2015-re ugyanezen mutató csökkenést mutatott, 1,9\%-ra csökkent, majd 2018-ra 4,1\% emelkedett. Azok, akiknél a személyes kapcsolatok hiánya, a magány fennáll, legfőképp

Az emberekbe vetett bizalmat 2013 óta mérik, 2015 óta minden évben. Bóday i. m. (68. lj.) 86-87.

Uo. 88.

Uo. 92.

Uo. 92. 
az idősebb korosztályból kerülnek ki, emellett nyugdíjon kívül az egyéb okok miatt inaktív státuszban lévő személyek között is magas a szociális elszigeteltség aránya ${ }^{84}$

A társadalom tagjainak kapcsolati hálóját szociális intézkedésekkel lehet bővíteni, mint például idősgondozási intézkedésekkel vagy olyan fejlett országos infrastruktúra kialakításával, amely lehetővé teszi, hogy az embereknek ne kelljen a családjuktól távol munkát vállalniuk. Az életszínvonal emelésének fontos lépése a szociális kapcsolatok felmérése, hiszen az ember számára elengedhetetlen a szociális élet bizonyos mértéke.

A társadalmon belül fontos lehet a civil szféra értékelése például a nonprofit szervezetek számával. A nonprofit szervezetek szintjén megvalósuló döntések nemcsak a szubszidiaritás elvének tesznek eleget, hanem a társadalmi csoportok integrációjában, a leszakadó csoportok felzárkózásában és az általános bizalom kiépítésében is jelentős szerepet játszanak. Több ilyen formában müködő hazai szervezet járul hozzá a gyermekek szociális és egyéb területeken való fejlődéséhez. A nonprofit szervezeteknek két formája van: az alapítványi és a társas nonprofit szervezet. Míg az alapítványi szervezetek száma az 1990-es évek óta 20 ezer körül stagnál, a társas nonprofit szervezetek esetében nagyfokú növekedést figyelhettünk meg, az érték 2017-ben 40 ezer felett volt. ${ }^{85}$

A társadalmi légkört szintén nagyban színesítő önkéntes munkát végző személyek száma közvetett módon kifejezi az emberek egymás iránt érzett szolidaritását. Az érettségihez kötött közösségi munka keretében a fiatalok egyre nagyobb köre végez önkéntes munkát, ami nagyban hozzájárul a világképük formálódásához és ezen keresztül egy összetartóbb, egészséges társadalomhoz. Magyarországon 2017-ben 2 millió 668 ezer fő végzett önkéntes munkát, ami az előtte lévő évekhez képest növekvő tendenciára utal. Kor szerinti csoportbontásban a 60 és 64 év közöttiek a legaktívabbak az önkéntes tevékenységekben, de a fent említett okok miatt az utóbbi években a fiatalok körében is nőtt az önkéntesek száma. Elmondható ezenfelül, hogy az önkéntes munkának továbbra is a közvetlen forma a legelterjedtebb módja, a megkérdezettek mindössze 7,1\%-a segített szervezett keretek között 2017-ben. ${ }^{86}$

A fenntartható demokrácia mérőszáma a részvételi arány a parlamenti választásokon. Országunkban a legutóbbi parlamenti választáson, 2018-ban a szavazásra jogosultak 70,2\%-a vett rész, ami kiemelkedő állampolgári aktivitásra utal. A régiókat tekintve a legtöbben Budapesten, a lakosság 75,4\%-a képviseltette magát, míg az északi régiókban az arány 65 és 68\% között alakult. A szavazati joggal való élés azért fontos indikátora egy országnak, mert kifejezi a polgárok politikával kapcsolatos érdeklődését, és azt, hogy mennyire érzik a szavazatukat döntő erejünek. Ilyen magas részvételi arány a szavazáson arra utal, hogy a társadalom érzi a leadott voksának a jelentőségét, vagyis érvényesülnek a demokrácia alapkeretei. ${ }^{87}$

Összefoglalva tehát a társadalmi fenntarthatóság indikátorait vizsgálva Magyarországon, megállapítható, hogy a kormányzat számos intézkedéssel igyekszik növelni

\footnotetext{
Bóday i. m. (68. lj.) 90.

Uo. 94.

Uo. 97.

Uo. 99.
} 
a lakosság életszínvonalát. Magyarországon az anyagi biztonság több mutató vizsgálása mentén is láthatóan a 2008-as gazdasági válság óta stabil. A lakosság bizalma embertársaikkal és a jogrendszerrel szemben is közepes szinten van, de ezt ellensúlyozza a kiemelkedően magas társadalmi aktivitás, a nonprofit szervezetek és az önkéntes munka révén.

Az indikátorok megfelelő szinten tartása azért is fontos, mert a vállalkozások érintettjei, azaz a munkavállalók és a fogyasztók anyagi biztonsága és életszínvonala kritikus hatással van az üzleti életre. Elengedhetetlen tehát, hogy a kormányzatok figyelmet fordítsanak olyan folyamatokra, mint a társadalmi egyenlőtlenség növekedése, a szegénység és a foglalkoztatottság arányainak változása, hogy a jelenlegi és a jövő generációi számára is biztosítsák az egészséges közösségekben megvalósuló életet. Amennyiben megfelelő intézkedésekkel és jogi szabályozással a társadalom fenntartható körülmények között tud létezni, az nagy hatással tud lenni az adott közösség életszínvonalára, és akár újabb piacok megnyitását is eredményezheti. A fenntarthatóság társadalompolitikai fejlődési céljainak hazai és európai uniós összehasonlítását az 1. táblázat tartalmazza.

1. táblázat • A társadalompolitikai fenntartható fejlődési célok hazai és európai uniós teljesülése (Forrás: https://ec.europa.eu/eurostat)

\begin{tabular}{|c|c|c|c|}
\hline $\begin{array}{l}\text { Fenntartható } \\
\text { fejlödési célok }\end{array}$ & $\begin{array}{l}\text { EU-s } \\
\text { teljesülés } \\
\text { (utolsó adat } \\
\text { szerint } \\
\text { 2017/2018) }\end{array}$ & Indikátorok & $\begin{array}{c}\text { Hazai teljesïlés } \\
\text { utolsó adat szerint } \\
(2017 / 2018)\end{array}$ \\
\hline \multirow{10}{*}{$\begin{array}{l}\text { 1. cél: } \\
\text { A szegénység } \\
\text { valamennyi } \\
\text { formájának } \\
\text { felszámolása } \\
\text { mindenhol. }\end{array}$} & $6,6 \%$ & $\begin{array}{l}\text { Anyagilag súlyosan nélkülöző } \\
\text { emberek. }\end{array}$ & $14,5 \%$ \\
\hline & $8,8 \%$ & $\begin{array}{l}\text { Háztartásokban élő emberek nagyon } \\
\text { alacsony munkaintenzitással. }\end{array}$ & $5,7 \%$ (60 év alatti lakosság) \\
\hline & $21,9 \%$ & $\begin{array}{l}\text { A szegénység vagy társadalmi kire- } \\
\text { kesztés veszélyének kitett emberek. }\end{array}$ & $\begin{array}{c}\text { 19,6\%-a a teljes } \\
\text { népességnek }\end{array}$ \\
\hline & $17,1 \%$ & $\begin{array}{l}\text { A jövedelemszegénység kockázatának } \\
\text { kitett emberek. }\end{array}$ & $12,8 \%$ \\
\hline & $9,5 \%$ & $\begin{array}{l}\text { A szegénység kockázatának kitett } \\
\text { (munkában lévők). }\end{array}$ & 8,4\% (18 < éves lakosság) \\
\hline & $\begin{array}{l}\text { Nő } 2,3 \% \\
\text { Férfi } 1,6 \%\end{array}$ & $\begin{array}{l}\text { Kielégítetlen igény az orvosi ellátásra } \\
\text { (önálló bejelentés alapján). }\end{array}$ & $\begin{array}{c}\text { Nő } 0,9 \% \\
\text { Férfi 0,7\% } \\
(16<\text { éves lakosság) }\end{array}$ \\
\hline & $1,7 \%$ & $\begin{array}{l}\text { A lakosság, amelynek háztartásában } \\
\text { sem kád, sem zuhany, sem beltéri } \\
\text { öblítős WC nem található. }\end{array}$ & $3,4 \%$ \\
\hline & $7,3 \%$ & $\begin{array}{l}\text { A lakosság nem képes melegen tar- } \\
\text { tani az otthonát. }\end{array}$ & $6,1 \%$ \\
\hline & $13,9 \%$ & $\begin{array}{l}\text { Szivárgó tetővel, nedves falakkal, } \\
\text { padlóval, alapokkal vagy rothadó } \\
\text { ablakkerettel vagy padlóval rendel- } \\
\text { kező lakosság. }\end{array}$ & $22,5 \%$ \\
\hline & $15,5 \%$ & $\begin{array}{c}\text { Túlzsúfoltság (zsúfoltan laknak } \\
\text { a lakásban pl. } 1 \text { szobában alszanak } \\
\text { a szülők és gyerekek). }\end{array}$ & $20,1 \%$ \\
\hline
\end{tabular}




\begin{tabular}{|c|c|c|c|}
\hline $\begin{array}{l}\text { Fenntartható } \\
\text { fejlödési célok }\end{array}$ & $\begin{array}{c}\text { EU-s } \\
\text { teljesülés } \\
\text { (utolsó adat } \\
\text { szerint } \\
\text { 2017/2018) } \\
\end{array}$ & Indikátorok & $\begin{array}{l}\text { Hazai teljesülés } \\
\text { utolsó adat szerint } \\
\quad(2017 / 2018)\end{array}$ \\
\hline \multirow{9}{*}{$\begin{array}{l}\text { 3. cél: } \\
\text { Az egészséges } \\
\text { élet biztosítása, } \\
\text { és a jóllét } \\
\text { előmozdítása } \\
\text { minden korosztály } \\
\text { valamennyi } \\
\text { tagjának. }\end{array}$} & $\begin{array}{l}\text { Nő: } 83,5 \\
\text { Férfi: } 78,3\end{array}$ & Születéskor a várható élettartam. & $\begin{array}{l}\text { Nő: } 79,3 \\
\text { Férfi: } 72,5 \\
\text { (év) }\end{array}$ \\
\hline & $\begin{array}{l}\text { Nő: } 66,9 \% \\
\text { Férfi: } 71,6 \%\end{array}$ & $\begin{array}{l}\text { Önértékelésen alapuló egészségi } \\
\text { állapot (jó, vagy nagyon jónak ítélt). }\end{array}$ & $\begin{array}{c}\text { Nő: } 57,6 \% \\
\text { Férfi: } 64,2 \% \\
\text { (16 év feletti lakosság) }\end{array}$ \\
\hline & - & A dohányzás gyakorisága & - \\
\hline & $18,3 \%$ & $\begin{array}{c}\text { A háztartásokban élő lakosság, akik } \\
\text { szenvednek a zajtól. }\end{array}$ & $8,5 \%$ \\
\hline & $\begin{array}{c}14,1\left(\mu \mathrm{g} / \mathrm{m}^{3}\right) \\
(2017 \text {-ben })\end{array}$ & Levegőszennyezésnek való kitettség. & $\begin{array}{c}20,2\left(\mu \mathrm{g} / \mathrm{m}^{3}\right) \\
(2014 \text {-ben })\end{array}$ \\
\hline & 119 fö & $\begin{array}{l}\text { Halálozási arány krónikus beteg- } \\
\text { ségek miatt. }\end{array}$ & $\begin{array}{c}\text { 243,7 fö (100 ezer } \\
\text { emberből - } 65 \text { év alatt) }\end{array}$ \\
\hline & 2,9 fö & $\begin{array}{l}\text { Tuberkulózis, HIV és hepatitis okozta } \\
\text { halálozási arány. }\end{array}$ & 2,6 fö (100 ezer emberből) \\
\hline & 4,9 fö & Közúti balesetekben meghaltak. & 6,4 fö (100 ezer emberből) \\
\hline & 1,65 fö & $\begin{array}{l}\text { Munkahelyi balesetek során meg- } \\
\text { haltak. }\end{array}$ & $\begin{array}{c}\text { 2,01 fő (100 ezer munka- } \\
\text { vállalóból) }\end{array}$ \\
\hline \multirow{7}{*}{$\begin{array}{l}\text { 4. cél: } \\
\text { Az inkluzív, } \\
\text { méltányos } \\
\text { és minőségi } \\
\text { oktatás biztosítása, } \\
\text { valamint } \\
\text { az élethosszig } \\
\text { tartó tanulás } \\
\text { lehetőségeinek } \\
\text { elősegítése } \\
\text { mindenki számára. }\end{array}$} & $10,6 \%$ & $\begin{array}{l}\text { Korai lemorzsolódás az oktatásból } \\
\text { és képzésből. }\end{array}$ & $\begin{array}{c}\text { 12,5\% (18 és } 24 \text { év } \\
\text { közöttiek) }\end{array}$ \\
\hline & $95,4 \%$ & $\begin{array}{l}\text { Részvétel a korai gyermekkori neve- } \\
\text { lésben. }\end{array}$ & $95,6 \%$ \\
\hline & $13,4 \%$ & $\begin{array}{l}\text { Fiatalok, akik nem vesznek részt sem } \\
\text { a foglalkoztatásban, sem az okta- } \\
\text { tásban, sem pedig képzésben. }\end{array}$ & $12,9 \%$ \\
\hline & - & $\begin{array}{l}\text { Elmaradás az olvasás, a matematika } \\
\text { és a tudomány területén. }\end{array}$ & - \\
\hline & $40,7 \%$ & Felsőfokú végzettség & $\begin{array}{c}\text { 33,7\% (30 és } 34 \text { év } \\
\text { közöttiek) }\end{array}$ \\
\hline & $81,7 \%$ & $\begin{array}{l}\text { A friss diplomások foglalkoztatási } \\
\text { rátája. }\end{array}$ & $87,5 \%$ \\
\hline & $11,1 \%$ & Felnőttek részvétele a tanulásban. & $6 \%$ \\
\hline
\end{tabular}

\section{KONKLÚZIÓ}

Jelen tanulmányunk a társadalmi fenntarthatóság témakörét, valamint annak hazai teljesülését vizsgálta. Az első fejezetben kitértünk a fenntarthatóság kialakulásának rövid összefoglalására, valamint a terminológiai megközelítéseire, és bemutattuk e konceptus bővülését és elterjedését mind nemzetközi, mind pedig hazai tekintetben. A második fejezetben a fenntarthatóság mérésére kidolgozott indikátorok bemutatására, valamint azoknak elméleti megközelítéseire és korlátaira szorítkoztunk.

$\mathrm{Az}$ áttekintés alapján kiderült, hogy a fenntarthatóság eszméjének régre nyúló történelmi gyökerei vannak, azonban a mai napig tudományos viták övezik. A megközelítéseknek és a mögöttük meghúzódó értelmezési és fogalmi vitáknak oka abban ragadható 
meg, hogy a fenntarthatóság és a fenntartható fejlődés elméleti megközelítései és iskolái részletesen kidolgozottnak tekinthetők, azonban e folyamatok mérésére kidolgozott indikátorok, illetve indikátorkészletek esetén nem találkozhatunk általánosan elfogadott keretekkel. A nemzetközi és hazai szakirodalmi áttekintés alapján több indikátort is kidolgoztak a fenntarthatóság vizsgálatára, ezek azonban merőben más szemszögből vizsgálják a fenntarthatósági folyamatokat, emellett nehezen hasonlíthatók össze eltérő módszertanuk és értékválasztásuk miatt.

A fenntarthatóságnak a fenntartható fejlődéssé való alakulási folyamatára igyekeztünk rámutatni, nemcsak terminológiai aspektusból, hanem a mögöttük álló mérhetőség témakörén keresztül is. 
1. 2019 a legmelegebb év 1901 óta Magyarországon. OMSZ, 2020. Elérhető: www.met. hu/omsz/OMSZ_hirek/index.php?id=2729\&hir=2019_a_legmelegebb_ev_1901_ota_ Magyarorszagon (A letöltés dátuma: 2020. 06. 01.)

2. Ayres, Robert U.: On the Practical Limits to Substitution. Ecological Economics, 61. (2007), 1. 115-128. DOI: https://doi.org/10.1016/j.ecolecon.2006.02.011

3. Bartus Gábor: A fenntartható fejlődés fogalom értelmezésének hatása az indikátorok kiválasztására. Statisztikai Szemle, 95. (2013a), 8-9. 842-869.

4. Bartus Gábor (szerk.): Nemzeti Fenntartható Fejlődési Keretstratégia. Nemzeti Fenntartható Fejlődési Tanács Titkára, 2013b.

5. Bauer, Dan H. - Raymond A. Fenn: The Corporate Social Audit. New York, Russell Sage Foundation, 1972.

6. Bell, Simon - Stephen Morse: Sustainability Indicators Past and Present: What Next? Sustainability, 10, (2018), 5. 1688. DOI: https://doi.org/10.3390/su10051688

7. Benn, Suzanne - Dianne Bolton: CSR iránytü - alapfogalmak, kulcskoncepciók. Budapest, Atlantis Press Kft., 2015.

8. Berkesné Rodek Nóra: CSR EMAT - A vállalatok társadalmi felelősségvállalásának kiválósági menedzsment és értékelési eszköze. Doktori értekezés. Veszprém, Pannon Egyetem, Gazdálkodás- és Szervezéstudományok Doktori Iskola, 2018. DOI: 10.18136/ PE.2018.683

9. Bóday Pál (szerk.): A fenntartható fejlödés indikátorai Magyarországon, 2018. Budapest, Központi Statisztikai Hivatal, 2019.

10. Braun Róbert: Vállalati társadalmi felelősségvállalás. A vállalatok politikája. Budapest, Akadémiai Kiadó, 2015. DOI: 10.1556/9789630597623

11. Carson, Rachel: Silent Spring. Houghton Mifflin, 1962.

12. Daly, Herman E. - John Cobb: For the Common Good. Boston, Beacon Press, 1989.

13. Du Pisani, Jacobus A.: Sustainable Development - Historical Roots of the Concept. EnvironmentalSciences, 3. (2006), 2.83-96. DOI:https://doi.org/10.1080/15693430600688831

14. Ehrlick, Paul R.: The Population Bomb. New York, Sierra Club/Ballantine Books, 1968.

15. Fleischer Tamás: A fenntarthatóság fogalmáról. In Knoll Imre - Lakatos Péter (szerk.): Közszolgálat és fenntarthatóság. Budapest, Nemzeti Közszolgálati Egyetem, 2014a. 9-24.

16. Fleischer Tamás: A fenntarthatóság mérése. In Knoll Imre - Lakatos Péter (szerk.): Közszolgálat és fenntarthatóság. Budapest, Nemzeti Közszolgálati Egyetem, 2014b. 25-47.

17. Getting Messages across Using Indicators - A Handbook Based on Experiences from Assessing Sustainable Development Indicators. Luxembourg, Eurostat, Publication Office of the European Union, 2014.

18. Havasi Éva: Az indikátorok, indikátorrendszerek jellemzői és statisztikai követelményei. Statisztikai Szemle, 85. (2007), 8. 677-689. 
19. Hendiani, Sepehr - Morteza Bagherpour: Development of Sustainability Index Using Z-Numbers: A New Possibilistic Hierarchial Model in the Context of Z-information. Environment, Development and Sustainability, 22. (2020), 7. 6077-6109. DOI: https:// doi.org/10.1007/s10668-019-00464-8

20. Human Development Report 2019. New York, United Nations Development Programme, 2019.

21. Jevons, William S.: The Coal Question: An Inquiry concerning the Progress of the Nation, and the Probable Exhaustion of our Coal-mines. London, Macmillan, 1865.

22. Karcagi-Kováts Andrea: Mivel mérjük a fenntarthatóságot? - Az indikátorkészletek helyzetértékelése az EU tagállamok nemzeti fenntartható fejlödési stratégiáiban. Doktori értekezés. Debrecen, Debreceni Egyetem, 2011.

23. Kárpáti Zoltán - Vári Anna - Ferencz Zoltán: Társadalmi fenntarthatósági indikátorok életciklus megközelítésben - egy kutatás tapasztalatai. Kultúra és Közösség, 2. (2011), 3. 15-28.

24. Keller Tamás: Javaslat a fenntartható fejlődés társadalmi indikátorainak mérésére. Mühelytanulmányok - No. 13. Budapest, Nemzeti Fenntartható Fejlődési Tanács, 2012.

25. Kerekes Sándor: A fenntarthatóság közgazdasági értelmezése. In Bulla Miklós - Tamás Pál (szerk.): Fenntartható fejlödés Magyarországon - Jövőképek és forgatókönyvek. Budapest, Új Mandátum, 2006. 196-211.

26. Kozma, Dorottya Edina: Comparative analysis of the sustainable development strategies and indicators of the V4. DETUROPE - The Central European Journal of Regional Development and Tourism, 11. (2019), 2. 101-120.

27. Kravchenko, Maria - Daniela C. A. Pigosso - Tim C. McAloone: A Procedure to Support Systematic Selection of Leading Indicators for Sustanability Performance Measurement of Circular Economy Initiatives. Sustainability, 12. (2020), 3. 951. DOI: https://doi.org/10.3390/su12030951

28. Kuznets, Simon: How to Judge Quality. Washington, D.C.: The New Republic, 1962.

29. Lior, Nolam - Mirjana Radovanović - Sanja Filipović: Comparing Sustainable Development Measurement Based on Different Priorities: Sustainable Development Goals, Economics, and Humal Well-Being - Southeast Europe Case. Sustainability Science, 13. (2018), 4. 973-1000. DOI: https://doi.org/10.1007/s11625-018-0557-2

30. Malthus, Thomas R.: Essay on the Principle of Population. London, Electronic Scholarly Publishing Project, 1998 [1798].

31. Markó Lilla: Mit jelent valójában a fenntartható fejlődés? - A fenntarthatóság és a fenntartható fejlődés fogalmi keretei. In Nyirkos Tamás (szerk.): Közös jövőnk - A fenntarthatóság elmélete és gyakorlata. Ostrakon Hallgatói Szervezetért Közhasznú Egyesület, 2017. 9-10. Elérhető: https://btk.ppke.hu/uploads/articles/956050/file/1704921\%20-\%20 P\%C3\%A1zm\%C3\%A1ny\%20Ostrakon\%20-\%20online_v2.pdf (A letöltés dátuma: 2020. 06. 01.)

32. Meadows, Donella H. - Dennis Meadows - Jorgen Randers - William Behrens: Limits to Growth. New York, Universe Books, 1972. 
33. Measuring Sustainable Development. New York and Geneva, United Nations Economic Commission for Europe, United Nations, 2009.

34. Mészáros Dóra: A mezőgazdaság fenntarthatóságát értékelő módszer fejlesztése. Doktori értekezés. Gödöllő, Szent István Egyetem, 2017. DOI: 10.14751/SZIE.2017.090

35. Pearce, David W. - R. Kerry Turner: Economics of Natural Resources and the Environment. Hemel Hempstead, Hertfordshire, Harvester Wheatsheaf, 1990.

36. Persányi Miklós (szerk.): Közös jövőnk. Budapest, Mezőgazdasági Kiadó, 1988.

37. Radácsi Lajos: A társadalmi felelősségvállalás könyve. 25 magyarországi vállalat rövid CSR jelentése. Budapest, Braun \& Partners Kft., 2008.

38. Stachó Krisztina: Világunk átalakítása: a fenntartható fejlődés 2030-ig szóló ENSZ-programja. In Nyirkos Tamás (szerk.): Közös jövőnk - A fenntarthatóság elmélete és gyakorlata. Ostrakon Hallgatói Szervezetért Közhasznú Egyesület, 2017. 9-10. Elérhető: https://btk. ppke.hu/uploads/articles/956050/file/1704921\%20-\%20P\%C3\%A1zm\%C3\%A1ny\%20 Ostrakon\%20-\%20online_v2.pdf (A letöltés dátuma: 2020. 06. 02.)

39. Stiglitz, Joseph - Amartya Sen - Jean-Paul Fitoussi: Report by the Commission on the Measurement of Economic Performance and Social Progress, 2009.

40. Stofleth, Danny: A Short History of Sustainable Development. Rethinking Proseperity Blog, 2017. 02. 23. Elérhető: http://rethinkingprosperity.org/a-short-history-ofsustainable-development/ (A letöltés dátuma: 2020. 06. 02.)

41. Sustainable transitions: policy and practice. EEA Report No. 9/2019. Luxembourg, European Environment Agency, 2019. DOI: 10.2800/641030

42. Szigeti Cecília: Az ökolábnyom és egyéb fenntarthatósági indikátorok mérési tartományának értelmezése. Journal of Central European Green Innovation, 3. (2015), 1. 49-68.

43. Szlávik János: Fenntartható környezet- és erőforrás-gazdálkodás. Budapest, KJKKERSZÖV, 2005.

44. Tasdemir, Cagatay - Rado Gazo - Henry J. Queseda: Sustainability Benchmarking Tool (SBT): Theoretical and Conceptual Model Proposition of a Composite Framework. Environment, Development and Sustainability, 22. (2020), 7. 6755-6797. DOI: https://doi.org/10.1007/s10668-019-00512-3

45. Vogel, David: The Market for Virtue - The Potential and Limits of Corporate Social Responsibility. Washington, D.C.: Brookings Institution Press, 2006.

46. Wackernagel, Mathis - William Rees: Our Ecological Footspring: Reducing Human Impact on the Earth. Philadelphia, PA, New Society Publishers, 1996.

Internetes források

1. https://ec.europa.eu/eurostat (A letöltés dátuma: 2020. 06. 01.)

2. Www.socialvalueuk.org/resources/sroi-guide/ (A letöltés dátuma: 2020. 06. 01.) 
Dr. habil. Boros Anita LL.M. a Nemzeti Közszolgálati Egyetem Államtudományi és Nemzetközi Tanulmányok Kar Lőrincz Lajos Közigazgatási Jogi Tanszékének egyetemi docense, korábbi tanszékvezetője. Több kitüntetés birtokosa (Köztársasági Ösztöndíj, Pro Regio-díj, miniszteri elismerés). 2010 óta több jelentős tisztsége van, így a Magyar Tudományos Akadémia köztestületi tagja, a Kodifikáció és Közigazgatás szerkesztőbizottsági tagja (2012-től), a Közbeszerzési Értesítő Plusz szerkesztőbizottságának tagja (2015-től), a Bírósági Szemle szerkesztőségének a tagja (2019-től), továbbá a Közbeszerzési Hatóság Tanácsának tagja, közigazgatási alap- és szakvizsgabizottsági elnök és tag, habilitációs bizottságok tagja, a Közigazgatási Eljárási Jogi Egyesület elnöke, a Magyar Jogász Egylet tagja. Jelenleg az Innovációs és Technológiai Minisztérium államtitkára. 2019 és 2020 között a Pro Publico Bono - Magyar Közigazgatás című folyóirat főszerkesztője, valamint 2010 és 2014 között a Közbeszerzési Szemle szerkesztőbizottságának elnöke. Kutatási területe a hazai és európai közigazgatási (hatósági) eljárásjog, a közszolgáltatások, a közbeszerzések és az állami beruházások fejlesztésének, valamint az állami vállalatok megfelelőségének és fenntarthatóságának egyes kérdései.

Hegedüs Viktor BSc-diplomáját 2015-ben szerezte a Pázmány Péter Katolikus Egyetem Bölcsész és Társadalomtudományi Kar nemzetközi tanulmányok képzésén. Ezt követően felvételt nyert a Nemzeti Közszolgálati Egyetem Államtudományi és Nemzetközi Tanulmányok Karának nemzetközi tanulmányok MSc-képzésére, ahol a tanulmányait jelenleg is folytatja. Alapképzési tanulmányai mellett aktívan részt vett a Pázmány Ostrakon öntevékeny hallgatói kör munkáiban, valamint a 2020 januárjában indult Magyar Közigazgatási Ösztöndíjprogramba is felvételt nyert.

Dr. Iván Dániel BSc-diplomáját 2012-ben szerezte a Nemzeti Közszolgálati Egyetem Közigazgatás-tudományi Kar igazgatásszervező képzésén. Ezt követően felvételt nyert az Egyetem közigazgatási MSc-képzésére, ahol 2014-ben diplomázott. 2017-ben a Pázmány Péter Katolikus Egyetem Jog- és Államtudományi Kar jogász szakán jogi doktorátust szerzett. Az okleveles közigazgatási menedzser diplomájának megszerzése után közvetlenül, még 2014-ben jelentkezett a Nemzeti Közszolgálati Egyetem Közigazgatástudományi Doktori Iskolájának doktori képzésére, és ezzel egyidejűleg tanársegédi állást kapott az egyetem Közjogi Intézet Európai és Összehasonlító Közjogi Tanszékén. 2019-től a Nemzeti Közszolgálati Egyetem Államtudományi és Nemzetközi Tanulmányok Kar Lőrincz Lajos Közigazgatási Jogi Tanszékének tanársegéde. 2013-ban elnyerte a Köztársasági Ösztöndíjat. Kutatási területei a közigazgatási eljárásjog, a közigazgatási szervezeti jog, önkormányzati jog és összehasonlító közigazgatás. 2018-tól tagja a Közigazgatási Eljárási Jogi Egyesületnek, 2019-től titkára. A Közigazgatási Eljárási Jogi Közlemények főszerkesztője. 